Fall 12-3-2021

\title{
Partnering with Hospital Providers to Facilitate Handoff for Persons with Dementia in the Acute Care Setting
}

Vanessa Jeune

University of St. Augustine for Health Sciences, v.jeune@usa.edu

DOI: https://doi.org/10.46409/sr.CPHF9051

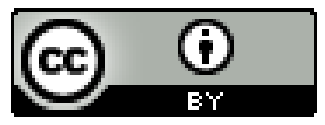

This work is licensed under a Creative Commons Attribution 4.0 License.

Follow this and additional works at: https://soar.usa.edu/scholprojects

Part of the Geriatric Nursing Commons, Geriatrics Commons, and the Interprofessional Education Commons

\section{Recommended Citation}

Jeune, V. (2021). Partnering with Hospital Providers to Facilitate Handoff for Persons with Dementia in the Acute Care Setting. [Doctoral project, University of St Augustine for Health Sciences]. SOAR @ USA: Student Scholarly Projects Collection. https://doi.org/10.46409/sr.CPHF9051

This Scholarly Project is brought to you for free and open access by the Student Research at SOAR @ USA. It has been accepted for inclusion in Student Scholarly Projects by an authorized administrator of SOAR @ USA. For more information, please contact soar@usa.edu, erobinson@usa.edu. 


\section{Partnering with Hospital Providers to Facilitate Handoff for}

Persons with Dementia in the Acute Care Setting

Vanessa Jeune, BSN, RN

School of Nursing, University of St. Augustine for Health Sciences

This Manuscript Partially Fulfills the Requirements for the

Doctor of Nursing Practice Program and is Approved by:

Mary Brann, DNP, RN

Karen Gilbert, DNP, MS, RN, CDP

December 3, 2021 


\begin{abstract}
Practice Problem: Individuals with Alzheimer's disease and related dementias cannot verbalize their care needs during transitions of care (TOC) and rely on their home caregivers (HCs) for advocacy. The lack of communication between clinicians in one setting and HCs can lead to detrimental health outcomes for the length of stay.

PICOT: The PICOT question that guided this project was: With the assistance of family nurse consultants $(\mathrm{P})$, how does the implementation of standardized care needs communication tool for support persons of persons with dementia (I) vs. no standardized process (C) enhance the ability for the support person to communicate care needs during TOC $(\mathrm{O})$ within 5 weeks $(\mathrm{T})$ ? Evidence: The review of high-quality studies reveals evidence that supports clinician-home caregiver communication as an approach to bridge gaps for the person with dementia (PWD) across health care settings.
\end{abstract}

Intervention: The clinician-home caregiver communication checklist was used as an evidencebased tool to enhance the HC's ability to communicate care needs for the PWD during care transitions.

Outcome: There was a clinically significant improvement with the family nurse consultants' utilization of the tool, and HCs who were offered the tool benefited from that time of preparation for their loved ones. There was a statistically significant improvement in family nurse consultants' perception of the value and usefulness of the tool after they were introduced to it. Conclusion: The project findings revealed that using the standardized care needs communication tool, HCs can be crucial members to strengthen TOC for the cognitively impaired individual. 


\section{Partnering with Hospital Providers to Facilitate Handoff for Persons with Dementia in the Acute Care Setting}

The dementia umbrella encompasses both Alzheimer's disease (AD) and other related disorders, and these conditions continue to raise concerns both nationally and worldwide (Alzheimer's Association, 2021). Individuals affected with Alzheimer's disease and related dementias (ADRD) also suffer from other comorbidities that need management, with approximately $96 \%$ of Medicare beneficiaries affected (Alzheimer's Association, 2021). The percentage of persons with dementia (PWD) also affected by other conditions is broken as followed: coronary artery disease (38\%), diabetes (37\%), chronic kidney disease (29\%), congestive heart failure (28\%), chronic obstructive pulmonary disease (25\%), stroke (22\%), and cancer at 13\% (Alzheimer's Association, 2021). When exacerbations from those chronic diseases cannot be managed in the home and primary care settings, the PWD necessitates a visit in the emergency department (ED) of a hospital, resulting in a hospital stay. The literature asserts that healthcare professionals providing care in the acute care setting often do not have the expertise to render care for individuals with ADRD (Galvin et al., 2010). Consequently, these individuals can be at increased risk of adverse care outcomes when hospitalized.

Home caregivers (HCs) remain an invaluable resource for this population while maintaining its dignity. As a result, it remains eminent to equip them with a communication tool that can benefit their loved ones when admitted to the hospital in meeting their needs, thus creating the most positive impact. Therefore, this scholarly project focuses on engaging them to communicate with hospital providers when those PWD transition in the acute care setting by implementing a standardized communication checklist with evidence based (EB) approaches that can tailor to their desires and patterns. 


\section{Significance of the Practice Problem}

ADRD are a global issue with approximately 47 million individuals diagnosed with dementia and a projected prevalence at 132 million in 2050 (Ryman et al., 2019). There are four different types of dementia, with AD making up $70 \%$ of all incidences, Lewy body dementia in second position affecting approximately 1.3 million Americans, then frontotemporal disorders, and vascular dementia (Alzheimer's Association, 2021). An estimated 4 million Americans live with ADRD (Deb et al., 2017), and more than 6 million individuals are affected by AD alone in the United States (Alzheimer's Association, 2021). In the state of Florida, approximately 580,000 residents are affected, representing 10\% of the national data (Alzheimer's Association, 2021). While prognosis can vary among affected individuals, the mortality for ADRD, with an increase of $146 \%$, is higher than both breast cancer and prostate cancer combined (Alzheimer's Association, 2021). This concern is serious across the nation, especially when half of the physicians feel unprepared to assure the provision of care for this growing population of demented individuals in the years to come (Alzheimer's Association, 2021).

The ED has experienced an increased $28 \%$ for individuals with ADRD and the main reasons for hospitalizations for PWD include ischemic heart disease, gastrointestinal disease, pneumonia, delirium, and change in mental status, with $26 \%$ of individuals with fall, syncope, and trauma (Alzheimer's Association, 2021). Nationwide, ED visits for individuals with dementia amount to $1.3 \%$, with a prevalence of 1,545 ED visits per 1,000 Medicare beneficiaries yearly (Alzheimer's Association, 2021). In the state of Florida, ED visits per 1,000 Medicare beneficiaries along with those that culminate in hospital admission add up to 1,551.9, the percentage of hospital stays followed by a readmission within 30 days cap at $23 \%$ and Medicare spending per capita range at 30,106 dollars (Alzheimer's Association, 2021). 
As dementia progresses in the late stages, the pathophysiology of ADRD is associated with both physiological and cognitive deficits. Over time, the affected individuals lose the ability to express their needs verbally, make decisions for themselves, and care for themselves such as performing their activities of daily living (Brodaty \& Donkin, 2009; Deb et al., 2017; Ryman et al., 2019). As a result, behaviors become their new means of communication. If not clearly understood and managed by the professional caregivers (PCs) in the acute care setting, these behavioral symptoms can be manifested as challenging or aggressive. Those PWD have an increased risk of death at $7 \%$ when hospitalized and are susceptible to spend an extra day in the acute care setting instead of those with no cognitive impairment (Alzheimer's Association, 2021). This aspect in the acute care setting is significant and can lead to morbidities and a higher risk for mortality. While morbidities and mortalities are more prominent in this population, so are healthcare costs. Deb et al. (2017) estimated the care for ADRD to cost the healthcare system up to 236 million dollars, however Alzheimer's Association (2021) reported costs up to 355 billion dollars nationally in 2021. Moreover, the medical expenditures are projected to surpass 1 trillion dollars in 2050 since the US population is aging (Alzheimer's Association, 2021; Deb et al., 2017) and payment for inpatient hospital service per PWD can add up to 11,933 dollars (Alzheimer's Association, 2021). Both the impact on the patient, the healthcare setting and the financial aspects associated with the disease devise a call for action. The situation is of utmost importance as it creates a disruption in the care and calls for a new adjustment to allow for this invaluable care continuity.

\section{PICOT Question}

With the assistance of family nurse consultants $(\mathrm{P})$, how does the implementation of a standardized care needs communication tool for support persons of PWD (I) vs no standardized 
process $(\mathrm{C})$ enhance the ability for the support person to communicate care needs during transitions of care $(\mathrm{O})$ within 5 weeks $(\mathrm{T})$ ?

\section{Population and Intervention}

The population included all family nurse consultants (FNCs) who assess all PWD enrolled in the organization throughout the stages of their disease and provide interventions. The EB intervention used the implementation of a plan of care communication tool for HCs to communicate the needs of the PWD to hospital providers when a change in the level of care is required.

\section{Comparison}

HCs for PWD are provided with emergency information forms to complete for both the PWD and themselves, which captured their personal health information and emergency contact, current medication list, insurance information, medical history, code status and living will information.

\section{Outcome and Timeline}

The desired outcome was to improve the capability of the informal caregiver (IC) of PWD to report to healthcare professionals in the acute care setting the needs of the PWD with the implementation of a standardized plan of care communication tool. This change in practice can help minimize disruptions for the PWD during a hospital length of stay (LOS). The FNCs needed to see value in the tool to promote it to the HCs. The implementation was set for 5 weeks.

\section{Evidence-Based Practice Framework and Change Theory}

Change in practice does not occur drastically. This section described the framework and change theory used to implement and guide this evidence-based practice (EBP) project. 


\section{Johns Hopkins Nursing Evidence-Based Practice Framework}

The Johns Hopkins Nursing Evidence-Based Practice (JHNEBP) framework is acknowledged for its use in clinical decision-making and problem-solving and comprises three different steps: practice question, evidence, and translation, also known as the PET process (Dang \& Dearhold, 2017). It will be described in greater details later in this paper.

\section{Haevelock: Six Phases of Planned Change}

Havelock's six phases of planned change helped build the foundation of this EBP project and guided the organization in adopting the change and sustain it. The six different phases included building a relationship, determining and prioritizing the problem, obtaining appropriate resources, finding the solution, gaining acceptance, and stabilizing the innovation (Kodama \& Fukahori, 2017; Mitchell, 2013). By building a relationship, the change agent (CA) identified the problem in collaboration with the key stakeholders and found EB approaches to mitigate the gap after searching the literature. The stakeholders aligned with the project's vision as demonstrated by participants' buy in into the activity and embracing the change (i.e., gaining acceptance).

Once the project was implemented, the FNCs completed the communication form to promote the sustainability of the intervention in the organization. They introduced the standardized communication checklist to the HCs to begin using the tool in preparation for their loved ones' hospitalization journey. Consistency with the process was of utmost importance, and monitoring for the latter ensured meaningful transformation, as demonstrated by the FNCs' success.

\section{Evidence Search Strategy}

A detailed and rigorous search was performed to locate articles that identify interventions for enhancing care delivery in the acute care setting for PWD by decreasing behaviors using the PICOT question. Cumulative Index to Nursing and Allied Health Literature (CINAHL), Pubmed, 
and Proquest databases were used to conduct the search. The keywords for that search comprised four primary constructs: (a) (caregivers or informal caregivers or relatives) and (b) (involvement or participation or engagement) and (c) (dementia patients or persons with dementia or Alzheimer's patients) and (d) (hospital staff or nurses or hospital setting or acute care setting). A quick internet search using Google Scholar was also performed.

Only for the search in Proquest the general limiter included searching the keywords on the abstract and the title only and that search revealed 38 articles. For the searches in Pubmed and CINAHL only the English language was applied as a filter. The search in Pubmed identified studies from 1989 - 2021, yielding 784 articles. To the searches on CINAHL, another general limiter included report-type (research article), and the default of the database was used for the time frame (1997-2021). All articles were published in the English language. Eligibility criteria included studies where the care was delivered in the hospital, involving both HCs and PWD. Studies with dementia-centered interventions to facilitate interaction between the IC and the one in the hospital were considered. Studies on PCs with no intervention to facilitate communication between clinicians and family caregivers (FCs) and the ones discussing caregivers for PWD, mental disorders and other chronic diseases combined were excluded.

\section{Evidence Search Results}

A Search conducted in three databases: Pubmed, CINAHL and ProQuest generated a total of 906 citations with PubMed, 755 citations; ProQuest 38 citations and CINAHL 113 citations. One article was also retrieved in Google Scholar, leading the initial search to a total of 907 articles. The titles and abstracts of 707 articles were initially screened. Once the inclusion and exclusion criteria were applied, about 50 articles were kept for additional screening. 
Furthermore, ten studies were found to yield the highest level of evidence, as demonstrated in the evidence table (see Appendices A and B). The PRISMA search strategy is illustrated in Figure 1.

For this project, the JHNEBP: Evidence Level and Quality Guide was utilized to appraise the selected citations. The 10 articles retrieved were analyzed based upon this model. Seven research articles were outlined in Appendix A, with one randomized controlled trial and a quantitative research article graded Level I of high quality, one with a pre and post design graded Level II of high quality, one prospective, exploratory design graded Level II of good quality, and two Level II mixed-study designs with good quality. A review article was graded Level III of good quality. Appendix B depicted an overview of three systematic reviews (SRs). The three SRs' strengths were Level I SRs of high quality, Further details reflecting each article's intervention, key findings, recommendations, and implications can be found in both Appendices $\mathrm{A}$ and $\mathrm{B}$.

\section{Themes with Practice Recommendations}

The literature search generated multiple studies suggesting that the clinician-informal caregiver communication improved on behalf of the individual with ADRD for dementiasuitable care in the hospital. Several commonalities have been noted within the different texts and presented.

\section{Family Engagement During Hospitalization to Improve Care}

The involvement of IC in sharing the needs of PWD to hospital providers and strategies on how to handle them is a priority that cannot be overlooked or underestimated. There is ample evidence that advocates for the engagement of the IC to provide input in the care of the PWD during a hospital stay (Isaac et al., 2018; Kelley et al., 2000; Rosenbloom-Brunton et al., 2010; Wu et al., 2020). Their knowledge and expertise in caring for these cognitively impaired 
individuals can enhance the provision of their clinical needs to mimic their daily routine while being in a different environment. Family involvement can surface at different levels. Not only can caregivers support their loved ones by communicating care strategies to unfamiliar staff members for meeting usual patterns and routines, but their involvement in the hospital care also consists of physically providing hands-on care during that episode of care (Boltz et al., 2015). As a result, hospital staff can view them as role models to help navigate this challenging time in a chaotic environment. This involvement in the care can offer many benefits to both the PWD, the IC, and the hospital staff. Many findings include a decreased fall rate and LOS, decreased occurrence of aggressive behaviors, and use of antipsychotic drugs, reduced utilization of hospital staff to provide one-to-one observation and decreased healthcare costs, improved patient health status, enhanced caregiver experience, and staff gratification (Boltz et al., 2015; Hirschman et al., 2018; Isaac et al., 2018; Kelley et al., 2000; Li et al., 2003; Luxford et al., 2015).

\section{Patient-Centered Approach with Communication Tool}

For the PWD, a transition from a familiar environment to a fast-paced hospital environment can be challenging due to unfamiliar stressors. There is a need for developing communication tools as a guide to orient hospital providers in performing the activity in acute care delivery. The different tools explored in the evidence table (see Appendices A and B) have proven to be effective during the hospitalization journey for PWD (Boltz et al., 2015; Isaac et al., 2018; Li et al., 2003; Luxford et al., 2015; Sampson et al., 2017). Whether TOP5, Family Involvement in Care (FIC), HELP, Whole system train the trainer model or Family-centered, function-focused care intervention (Fam-FFC) was utilized, all tools were designed to improve the PWD's patient/family-centered care health status, decrease complications and risk for 
rehospitalizations. With TOP5 implementation, a significant reduction of falls, LOS, and use of chemical restraints were noted (Isaac et al., 2018; Luxford et al., 2015) while a significant reduction of delirium, acute confusion rate, and readmission rate with FIC, Fam-FFC, and Creating avenues for relative empowerment (CARE) program (Boltz et al., 2015; Kelley et al., 2000; Li et al., 2003). In studies conducted by Boltz et al. (2015) and Li et al. (2003), the results with patient care were impressive during the hospital stay, and patients maintain remarkable functional recovery up to two months post-discharge.

\section{Staff Education}

Through education, ICs can see value in communicating the needs for PWD during a change of condition to enhance safety for that population and feel empowered to offer that support. To enable the implementation of the communication tool, leadership support in the organization is vital, as well as the presence of champions or liaison members, and the display of visual aids such as posters to assure sustainability (Luxford et al., 2015; Rosenbloom-Brunton et al., 2010; Wu et al., 2020). The literature also asserts that education for staff in the receiving organization (i.e., the hospital) is essential for a better partnership. Nurses who are educated on the clinical presentation of the disease are more likely to effectively collaborate with the HC to benefit the PWD in the acute setting (Hirschman et al., 2018; Rosenbloom-Brunton et al., 2010). During the establishment phase of the TOP5 intervention, Isaac et al. (2018) asserts that 100\% of nurses reported engagement with ICs to obtain valuable information about the hospitalized patient to provide individualized care. As a result, nurses will facilitate the communication process for HCs to participate in the program, be prone to listen to the ICs for insightful strategies, and value that information shared due to their ability to engage in conversations with ICs. 


\section{Practice Recommendations}

A plan of care communication tool with a patient-centered approach to include strategies that meet the needs of the PWD during hospitalizations has been demonstrated to bolster a successful visit or stay in the hospital (see Appendices A and B). The practice recommendation of this project has been to implement a caregiver-hospital provider communication checklist within an institution that renders services to both individuals with ADRD and their ICs. All caregivers (i.e., already enrolled, and incoming) in the organization would be encouraged to complete the EB tool early for better preparedness with caregiving and transfer to the acute care setting should a change of health condition requires the latter (Alzheimer's Association, 2020; Boltz et al., 2015; Hirschman et al., 2018; Kelley et al., 2000). With the support of the FNC, this implementation of the standardized care needs communication tool allowed the IC to be a relevant member in the planning, provision, and coordination of care for the PWD in the acute healthcare setting. More important, the tool has allowed for care to be specific for each patient. Lastly, the costs associated with implementing the intervention within the organization were minimal at 540 dollars (see Table 1).

\section{Setting, Stakeholders and Systems Change}

\section{Project Overview}

The setting for this project was a not-for-profit organization whose mission consists of providing dementia-specific care to both the PWD and the IC through a community-based approach. Services provided include the adult daycare center services at 11 different sites, electronic safety device monitoring, 24-hour crisis line, community education, case management and partnership with law enforcement to fulfill its mission. There is a well-defined chain of command in the structure of the organization with a 12-member Board of Directors, the Chief 
Executive Officer (CEO), the Vice President of Education and Quality Assurance (VPEQA), the Vice President of Community Care Services (VPCCS). The next level includes Director of FNCs, Specialized Day Service Director, Director of ID Locator Service, Director of Case Management, and direct care staff (i.e., Program Manager, Program Assistant, ID Locator Assistant, and FNCs who report to the different Directors already presented).

The Doctor of Nursing Practice (DNP) student met with the VPEQA to assess the practice of the organization. That assessment revealed a lack of standardized process for caregivers to communicate the needs of their loved ones to hospital providers should a change in the level of their care be needed. While HCs are encouraged to fill out the emergency information form for themselves and the PWD, they have no resources and guidance on how to contribute to a successful hospitalization for their cognitively impaired loved ones through communication. This gap in communication issues was also presented to the CEO. During that time, a Strengths, Weaknesses, Opportunities, and Threats (SWOT) analysis, illustrated in Appendix C, was performed to assess the current situation of the HCs' strategy project and the dynamic between the setting and the project. Organizational support from the CEO, the VPEQA, and FNCs who are key stakeholders and part of the interprofessional team was necessary and was obtained based upon the strategic plan of creating a dementia-friendly hospital experience for the PWD. The FNCs were the primary champions to assure sustainability and their roles were crucial to assure maximum support and successful project outcomes.

The interprofessional team established plans for project sustainability once the intervention was implemented and evaluated for effectiveness. The FNCs educated the HCs on effective communication with healthcare providers to ensure high-quality care for PWD and their role of completing the form contribute to that care. To facilitate the access of the tool to the HCs, 
the DNP student suggested that the FNCs fold the form, place it in the plastic pouch labeled "Clinician-Caregiver Communication form," and add it to the patients' packet for both incoming and currently enrolled cognitively impaired individuals. Moreover, the facility has a website, and a Certified Senior Advisors journal printed every 2 months where this tool can be visible.

Should the change project demonstrate looming success, this journal will be valuable to report these positive caregiver outcomes to help sustain this project adequately.

\section{Implementation Plan with Timeline and Budget}

\section{Objectives}

Short-term objectives identified for the project were that FNCs incorporated the tool into practice adequately so that caregivers can effectively share the vulnerabilities and care needs of the PWD during hospitalization. The expectation was that $80 \%$ of the FNCs noticed the value in the tool and $50 \%$ of them used the form to facilitate HCs to complete the form after meeting with that champion. Moreover, $50 \%$ of the participants were anticipated to report that HCs have a beneficial influence in the acute setting when the tool is utilized for communicating dementia care needs for the cognitively impaired person. The primary long-term objective was for the FNCs to sustain the form by ensuring that the $\mathrm{HC}$ will adopt the skills learned and use the service available to them throughout the care continuum to help decrease behaviors for the PWD during the hospital stay. Another long-term objective included the dissemination of the project findings within a year of implementation.

\section{Johns Hopkins Nursing Evidence-Based Practice Framework}

The PET process guided the planning, implementation, and evaluation phases for this project. To better visualize the different activities during the EBP project, a Gantt chart outlined the project events' timeline in Appendix D. 


\section{Planning Phase}

Both phase one (practice question) and phase two (evidence) of the PET process were completed during the planning phase. During that step, the topic of interest for change improvement to reduce the communication gap when the PWD is in the hospital was selected and a literature search was performed for the most current evidence to address the need for a communication form for use by ICs. During that time, a SWOT analysis was envisioned to account for risks and barriers that could lead to the likelihood of an unsuccessful project. Likewise, favorable factors were also captured before implementing this project. A practice recommendation was developed, which prompted to the acquirement of the clinician-informal caregiver communication form. The proposal was then submitted for approval to the VPEQA and the EBP committee.

\section{Implementation Phase}

Phase three (translation) of the JHNEBP model entailed the implementation project, the evaluation, and plan to disseminate the findings (Dang et al., 2017). The implementation of the project did not begin until after the DNP student received approval from the EBP committee. During that period, the plan focused on capturing if the FNCs feel a gap exists in communication care needs for cognitively impaired individuals and if the tool can help bridge that gap. The DNP student met the FNCs during a one-hour Teams meeting where she explained the purpose of the project and the practice gap identified, revealed an overview of evidence, displayed the form and how it is used. Time was also allotted for questions. All participants were provided one continuing education unit for attending the presentation. The FNCs were accountable to use the tool in perpetuity with all $\mathrm{HCs}$ at the time of enrollment, recertification and at the time of change of condition so it will be a sustainable change. 


\section{Evaluation Phase}

This plan continued during the translation phase of PET (Dang et al., 2017). Both preand post-implementation data were appraised to determine if statistical and clinical significance occurred. The data consisted of process, balancing, financial, outcome and sustainability measures (see Table 2). The table also outlined the different variables, the source of the data, the level of measurement for variables, and the period for data collection. Benchmarks are also defined in Table 3. The project manager (PM) monitored FNCs' perceptions of usefulness of the tool, compliance with using the communication tool, measured and interpreted the data to determine the outcomes, and assessed the intervention's efficacy.

\section{Validity and Reliability of Tools}

The caregiver surveys pre (see Appendix E) and post project implementation (see Appendices F and G) were developed by the DNP student. The clinician-caregiver communication tool (see Appendix H) is based upon EB literature and guidelines from the Alzheimer's Association proven effective in prominent levels of evidence. The DNP preceptor was instrumental in providing feedback for the surveys constructed to measure FNCs' perceptions. The DNP student also sought feedback from her DNP preceptor and her faculty member to assure that the content of the tool was relevant and that it identified to enhance communication among both parties.

\section{Role of the Project Manager and Leadership Skills}

Like the FNC, the PM played a paramount role in supporting the accomplishment of this project. The PM maintained to communicate clearly with all participants, assured that they understood their contribution to the implementation of the project, to assure that objectives were being met. Moreover, the PM did build harmonious relationships with the FNCs, engaged the 
team, developed buy-in, provided objective feedback, and fostered a psychologically safe milieu (Weiss et al., 2016). Lastly, the ongoing encouragement has been valuable to support behavior change.

\section{Project Results}

\section{Selection of Participants and Data Integrity}

Participants were FNCs who were explained the course of the project and informed of the DNP student's presentation of the communication tool as they can speak, read and write in the English language. A total of eight FNCs participated in the project. To maintain their privacy, the DNP student asked them to print their initials when completing the pre-and post-project surveys to assist her in accurate data collection and analysis. The PM did not have the participants' names to identify the initials. The survey did not collect any other personal identifier. The FNCs were also informed to anticipate another survey within 30 days for follow-up remarks.

\section{Family Nurse Consultant Perceptions of Usefulness of the Communication Care Needs Tool}

Before the presentation, the PM administered a five-question four-point Likert scale survey to capture the FNCs' perceptions of the lack of communication between the HCs and hospital clinicians during the PWD's hospitalization. An identical survey with five different questions was also distributed after the PM presented the tool. The VPEQA distributed the surveys to the participants via email before implementing the project on September 13, 2021, and after the PM's PowerPoint presentation on September 16, 2021. The two surveys were available for 2 days each.

Both surveys (see Appendices E and F) reflect a Likert scale format with the following answers: $1=$ strongly disagree, $2=$ disagree, $3=$ agree, $4=$ strongly agree, and gathered ordinal 
data. The FNCs returned their completed surveys to the VPEQA via email. The latter then scanned all documents, uploaded them in one pdf file, and emailed the attached document to the PM's school email. The PM used her password-locked computer to access the data. She transferred the latter to an Excel spreadsheet, then uploaded it to the Intellectus software to calculate the statistical data. FNCs were provided a third survey (see Appendix G) via email with the request to submit it back to the organization in 30 days to see if they used the tool, had any additional perception of usefulness after interacting with the tool, and if HCs benefited from that preparation. Four of the questions gathered ordinal data due to the Likert scale format and the last question yielded scale data.

\section{Data Analysis}

The majority of FNCs (87.5\%) strongly believed that the HC should share vulnerabilities about the PWD during hospitalization and TOC, which suggests their concerns about the PWD who incapable of communicating his own needs pertinent to his care. However, as a support person for the $\mathrm{HC}, 37.5 \%$ of the participants strongly agreed to be familiar with the vital information the $\mathrm{HC}$ needs to provide to the hospital caregivers about the PWD. Moreover, 37.5\% strongly agreed and $62.5 \%$ agreed that the clinicians in the acute care setting are not aware of what it takes to provide care to the cognitively impaired individuals affected by ADRD. These results are presented in Table 4.

After the presentation, $87.5 \%$ of them strongly perceived that this change in practice could decrease fragmentation in the care of the PWD during the hospital stay. Concurrently, $87.5 \%$ of the FNCs strongly believed they can educate the HCs on the use of tool, strongly felt the tool is valuable and needed to provide it to the $\mathrm{HC}$ to enhance safety for the PWD during hospitalization, and strongly believed they can educate the $\mathrm{HCs}$ on how to use it. Before the 
presentation, $50 \%$ of the FNCs strongly saw the HCs' contribution to acute care as a positive mechanism for the PWD. In comparison, an increased percentage of $62 \%$ asserted that the HCs would positively impact acute care and TOC when the form is used as a tool to plan and communicate care needs. Those statistics suggested that they saw value in providing the communication tool proactively to $\mathrm{HCs}$ and for HCs to use it for that person with a cognitive deficit as a means of ensuring their protection from harm during hospitalization. Table 5 reflects the frequencies and percentages for the post survey results.

A two-tailed Wilcoxon signed-rank test was conducted to investigate whether there was a significant difference between the scores of the pre-survey (Pre.Question.Overall) and postsurvey (Post.Question.Overall). The results of the two-tailed Wilcoxon signed-rank test were significant based on an alpha value of $0.05, V=0.00, z=-2.06, p=.039$. The median of Pre.Question.Overall $(\mathrm{Mdn}=3.50)$ was significantly lower than the median of Post.Question.Overall ( $\mathrm{Mdn}=3.90)$, indicating a statistically significant improvement in the FNCs' perceptions of the value and usefulness of the tool after the DNP student's presentation. Figure 2 presents a boxplot of the ranked values of Pre.Question.Overall and Post.Question.Overall.

\section{Family Nurse Consultant Use of Clinician-Caregiver Communication Form in Practice}

A third survey was administered 30 days after the project implementation to the eight FNCs, and seven of them ( $n=7$, an $87.5 \%$ response rate) completed it because one of the FNCs was no longer employed at the organization. The most frequently observed category for all questions of the post 30-day questionnaire was strongly agree (SA). The FNCs still perceived the tool to safeguard individuals with ADRD with 71\% SA and 29\% agree (A) for Q2-Post 30 days and $86 \%$ SA and 14\% A Q4-Post 30days. Moreover, three of the seven participants reported 
using the tool $(n=3)$ with a frequency of five tools used $(n=5)$, accounting for a $43 \%$ utilization rate of the communication form. The average number of times the tool was used is 0.71 . The results are presented in Tables 6 and 7. The observed utilization rate was below the anticipated goal of $50 \%$ for 30 days. All data collected was provided to the participants and the organizations' leadership to decide if changes need to be enacted for sustainability of the form at the different adult day care centers.

\section{Impact}

The DNP project had a significant impact on the organization and the survey results obtained during the EB project indicated that the form developed for the project was beneficial for HCs. Before the project, the facility did not have a tool to facilitate communication for their loved ones with ADRD to staff in the acute care setting. The tool was new to the FNCs, and the output generated a $43 \%$ utilization rate. FNCs' perceptions of the form increased as demonstrated by both descriptive statistics and a $p<0.05$. Aspects of clinical significance included the FNCs' confidence level and comfort level in discussing the tool with caregivers. On average, responders answered "strongly agree" or "agree" for those categories. The post-30-day survey questions demonstrated that the FNCs' perceptions strengthened over time as to the importance of providing HCs with a tool to communicate patient vulnerabilities to hospital and rehabilitation staff. One participant shared that she used the tool to inform the hospital and rehabilitation facility about the unique needs of a family member who was hospitalized after a fall and transferred to rehabilitation for two weeks. The latter further asserted that staff at both organizations were appreciative to obtain that information. It certainly cannot be harmful for unfamiliar caregivers from a different setting to know more about the adjustments that must be met for patients with ADRD. In addition, until frequent interactions are occurring between FNCs 
and HCs, FNCs can use the time of the initial evaluation for PWD and their HCs and their yearly follow-up to present the tool to HCs, which can assist unfamiliar carers in the acute care setting with caregiving understand the PWD's routines and patterns for better hospitalization journey.

\section{Limitations}

After the presentation, the participants saw a possibility for HCs to partner with hospital staff during an acute care situation. However, there was a suboptimal utilization of the tool to equip the caregivers. The current surge of the COVID 19 pandemic with the delta variant plays a massive factor in that regard. The VPEQA reported the nonoperational status of the support groups and the caregivers not giving access to FNCs in their homes for non-emergent matters (VPEQA, personal communication, September 30, 2021). Nonetheless, the caregivers who benefited from the tool are taught to identify things early to prevent the cognitively impaired individual from being hospitalized.

Moreover, the project was constrained to a 5-week implementation time frame and the sample for the project was minimal, which led to limited data. A longer intervention window would be deemed necessary to obtain FNCs' feedback from the use of the tool, allowing them to support the HCs and report if the HCs engaged in using the tool and find it beneficial. A longer timeline would guarantee more accurate data about HCs' perception of the tool's value, engagement with the tool, and the extent to utilize it for their loved ones. Lastly, a larger population of FNCs might be considered for further projects to gather more factual measurements. 


\section{Dissemination Plan}

The findings of the project were shared with the key stakeholders of the organization via a PowerPoint presentation at a Teams meeting. The resources used during project implementation were also shared with the VPEQA. The latter will use the findings to guide sustainability of the tool with both the FNCs and HCs in the organization. The DNP scholarly paper will also be submitted to the University of Saint Augustine for Health Sciences SOAR repository to display the manuscript to the interested entities.

On a state level, another venue for presentation will include the Florida Nurse Association Annual Nursing Research and Evidence-Based practice conference that occurs every July. A poster presentation in that conference will allow the PM to reach out to stakeholders such as ICs for PWD, hospital providers, and leaders who understand the essence of the project. Moreover, an abstract will be submitted to either The Gerontologist or the Journal of Alzheimer's Disease because they are peer-reviewed journals that focus not only on the improved health and function of PWD but also on the HC's involvement in that journey. Lastly, the project has implications for nurses, $\mathrm{HCs}$, and other interprofessional team members, such as social workers and case managers. Hence, the PM will network the communication checklist in areas where HCs will benefit from it.

\section{Conclusion}

As the cognitive health of PWD deteriorates progressively, ICs become more involved with caregiving. The standardized care needs communication tool is meant to organize thoughts that increase communication between the IC and the next team. Therefore, sharing strategies on caring for the PWD to unfamiliar staff positively impacts cognitively impaired individuals. 
The project did not demonstrate the ICs' involvement with the tool, yet the results showed promising due to the champions' perceived value. As the caregiver support groups return to function, the FNC will use that platform to introduce the communication tool to caregivers, encourage them to complete the form, keep it in a safe zone within reach, and provide support to them as needed. In the end, enhancing the IC's ability to communicate care needs during change of care can help mitigate unnecessary challenges throughout caregiving in the hospital setting (Alzheimer's Association, 2021; Boltz et al., 2015; Hirschman et al., 2018; Kelley et al., 2000). 


\section{References}

Alzheimer's Association. (2020). Communicating with doctors or health care professionals. https://www.alz.org/media/documents/alzheimers-dementia-communicating-doctorhealth-care-pro-ts.pdf

Alzheimer's Association. (2021). 2021 Alzheimer's and dementia facts and figures. Alzheimer's \& Dementia: The Journal of the Alzheimer's Association, 17(3), 327-406. https://doi.org/10.1002/alz.12328

Beardon, S., Patel, K., Davies, B., \& Ward, H. (2018). Informal carers' perspectives on the delivery of acute hospital care for patients with dementia: a systematic review. BMC Geriatrics, 18(1), 1-11. https://bmcgeriatr.biomedcentral.com/articles/10.1186/s12877$\underline{018-0710-\mathrm{X}}$

Boltz, M., Chippendale, T., Resnick, B., \& Galvin, J. E. (2015). Testing family-centered, function-focused care in hospitalized persons with dementia. Neurodegenerative Disease Management, 5(3), 203-215. https://doi.org/10.2217/nmt.15.10

Brodaty, H., \& Donkin, M. (2009). Family caregivers of people with dementia. Dialogues in Clinical Neuroscience, 11(2), 217-228. https://doi.org/10.31887/DCNS.2009.11.2/hbrodaty

Dang, D., \& Dearholt, S. L. (2017). Johns Hopkins nursing evidence-based practice: Model and guidelines. Sigma Theta Tau.

Deb, A., Thornton, J. D., Sambamoorthi, U., \& Innes, K. (2017). Direct and indirect cost of managing Alzheimer's disease and related dementias in the United States. Expert Review of Pharmacoeconomics \& Outcomes Research, 17(2), 189-202. https://doi.org/10.1080/14737167.2017.1313118 
Galvin, J. E., Kuntemeier, B., Al-Hammadi, N., Germino, J., Murphy-White, M., \& McGillick, J. (2010). "Dementia-friendly hospitals: Care not crisis": An educational program designed to improve the care of the hospitalized patient with dementia. Alzheimer Disease and Associated Disorders, 24(4), 372-379. https://doi.org/10.1097/WAD.0b013e3181e9f829

Hirschman, K. B., \& Hodgson, N. A. (2018). Evidence-based interventions for transitions in care for individuals living with dementia. The Gerontologist, 58, S129-S140. https://academic.oup.com/gerontologist/article/58/suppl_1/S129/4816738

Isaac, L. M., Buggy, E., Sharma, A., Karberis, A., Maddock, K. M., \& Weston, K. M. (2018). Enhancing hospital care of patients with cognitive impairment. International Journal of Health Care Quality Assurance 31(2), 173-186. https://doi.org/10.1108/IJHCQA-11$\underline{2016-0173}$

Kelley, L. S., Specht, J. K. P., \& Maas, M. L. (2000). Family involvement in care for individuals with dementia protocol. Journal of Gerontological Nursing, 26(2), 13-21. https://prxusa.lirn.net/login?url=https://www.proquest.com/scholarly-journals/family-involvementcare-individuals-with-dementia/docview/204190834/se-2?accountid=158603

Kodama, Y., \& Fukahori, H. (2017). Nurse managers' attributes to promote change in their wards: A qualitative study. Nursing Open, 4(4), 209-217. https://doi.org/10.1002/nop2.87

Li, H., Melnyk, B.M., Mccann, R., Chatcheydang, J., Koulouglioti, C., Nichols, L.W., Lee, M.D., Ghassemi, A. (2003). Creating avenues for relative empowerment (CARE): A pilot test of an intervention to improve outcomes of hospitalized elders and family caregivers. Research in Nursing \& Health 26, 284-299. https://doi.org/10.1002/nur.10091 
Luxford, K., Axam, A., Hasnip, F., Dobrohotoff, J., Strudwick, M., Reeve, R., Hou, C., \& Viney, R. (2015). Improving clinician-carer communication for safer hospital care: A study of the 'TOP 5'strategy in patients with dementia. International Journal for Quality in Health Care, 27(3), 175-182. https://doi.org/10.1093/intqhc/mzv026

Mitchell, G. (2013). Selecting the best theory to implement planned change. Nursing Management, 20(1), 32-37. https://doi.org/10.7748/nm2013.04.20.1.32.e1013

Rosenbloom-Brunton, D. A., Henneman, E. A., \& Inouye, S. K. (2010). Feasibility of family participation in a delirium prevention program for hospitalized older adults. Journal of Gerontological Nursing, 36(9), 22-33. http://dx.doi.org/10.3928/00989134-20100330-02

Ryman, F. V., Erisman, J. C., Darvey, L. M., Osborne, J., Swartsenburg, E., \& Syurina, E. V. (2019). Health effects of the relocation of patients with dementia: A scoping review to inform medical and policy decision-making. The Gerontologist, 59(6), e674-e682. https://doi.org/10.1093/geront/gny031.

Sampson, E. L., Vickerstaff, V., Lietz, S., \& Orrell, M. (2017). Improving the care of people with dementia in general hospitals: Evaluation of a whole-system train-the-trainer model. International Psychogeriatrics, 29(4), 605-614. https://doi.org/10.1017/S1041610216002222

Weiss, D., Tilin, F., \& Morgan, M. (2016). The interprofessional health care team: Leadership and development (2nd ed.). Jones \& Bartlett Learning.

Wu, Q., Qian, S., Deng, C., \& Yu, P. (2020). Understanding interactions between caregivers and care recipients in person-centered dementia care: A rapid review. Clinical Interventions in Aging, 15, 1637-1647. https://doi.org/10.2147/CIA.S255454 


\section{Table 1}

Budget for the DNP Project

\begin{tabular}{|l|c|}
\hline \multicolumn{1}{|c|}{ Expenses } & Costs \\
\hline Statistician fee (paid by the DNP student to & $\$ 100$ \\
help with data analysis) & $\$ 100$ \\
\hline Ziplock bags to place form in patients' charts & \\
(as suggested by the DNP student) & $\$ 100$ \\
\hline Communication care needs tool (cost of paper & $\$ 240$ \\
\hline Financial cost for training FNCs & $\$ 540$ \\
\hline Total & \\
\hline
\end{tabular}




\section{Table 2}

Project Variables and Categories of Measures

\begin{tabular}{|c|c|c|c|c|c|c|c|}
\hline & Categories & $\begin{array}{l}\text { Variable } \\
\text { Description }\end{array}$ & $\begin{array}{l}\text { Data } \\
\text { Source }\end{array}$ & $\begin{array}{l}\text { Possible } \\
\text { Range } \\
\text { of } \\
\text { Values }\end{array}$ & $\begin{array}{l}\text { Level of } \\
\text { Measurement }\end{array}$ & $\begin{array}{l}\text { Categories of } \\
\text { measures }\end{array}$ & $\begin{array}{l}\text { Time Frame for } \\
\text { Collection }\end{array}$ \\
\hline Population & $\begin{array}{l}\text { Family Nurse } \\
\text { Consultants } \\
\text { (FNCs) }\end{array}$ & Initials & $\begin{array}{l}\text { FNCs } \\
\text { printed } \\
\text { in the } \\
\text { survey } \\
\text { forms }\end{array}$ & N/A & Nominal & N/A & $\begin{array}{l}\text { When FNC } \\
\text { completes the } \\
\text { surveys }\end{array}$ \\
\hline Event & $\begin{array}{l}\text { Clinician- } \\
\text { Caregiver } \\
\text { Communication } \\
\text { Form }\end{array}$ & $\begin{array}{l}\text { Project Manager } \\
\text { presented tool to } \\
\text { the FNCs. In turn, } \\
\text { the tool was } \\
\text { provided by the } \\
\text { FNC to the } \\
\text { caregiver to } \\
\text { inform hospital } \\
\text { providers of the } \\
\text { needs of the } \\
\text { PWD during an } \\
\text { acute situation. } \\
\text { This tool has } \\
\text { good face validity }\end{array}$ & & & & Process & \\
\hline
\end{tabular}




\begin{tabular}{|c|c|c|c|c|c|c|}
\hline Outcomes & $\begin{array}{l}\text { Improved } \\
\text { FNC's } \\
\text { perception of } \\
\text { usefulness of } \\
\text { tool } \\
\text { FNC utilization } \\
\text { of form: FNC } \\
\text { to champion the } \\
\text { tool for } \\
\text { sustainability }\end{array}$ & $\begin{array}{l}\text { Clinician- } \\
\text { Caregiver } \\
\text { Communication } \\
\text { Form. } \\
\text { Tool with good } \\
\text { face validity }\end{array}$ & $\begin{array}{l}\text { Pre and } \\
\text { post } \\
\text { Likert } \\
\text { scale } \\
\text { surveys } \\
\text { Post } \\
\text { 30-day } \\
\text { Likert } \\
\text { scale } \\
\text { survey }\end{array}$ & Ordinal & $\begin{array}{l}\text { Outcome, } \\
\text { Financial, } \\
\text { Process, } \\
\text { Sustainability }\end{array}$ & $\begin{array}{l}\text { Pre and Post } \\
\text { intervention } \\
\text { implementation }\end{array}$ \\
\hline
\end{tabular}




\section{Table 3}

Benchmarks

\begin{tabular}{|c|c|c|c|c|c|c|c|c|c|c|c|c|c|c|c|c|c|c|c|c|c|}
\hline \multirow{3}{*}{$\begin{array}{c}\text { MEASURES } \\
\text { Name \& Metric }\end{array}$} & \multirow{3}{*}{ Outcom } & \multirow{2}{*}{\multicolumn{3}{|c|}{ CATEGORIES }} & \multirow{3}{*}{\multicolumn{2}{|c|}{$\begin{array}{l}\text { Sustainabilit Contextual } \\
y \quad \text { C }\end{array}$}} & \multirow{2}{*}{\multicolumn{3}{|c|}{ Time for Data Collection }} & \multirow{2}{*}{\multicolumn{2}{|c|}{ Statistical Test }} & \multirow{3}{*}{$\begin{array}{l}\text { Define the } \\
\text { Clinically } \\
\text { meaningfu } \\
\text { I criteria }\end{array}$} & \multirow{3}{*}{$\begin{array}{l}\text { BASELINE } \\
\text { Pre } \\
\text { presentati } \\
\text { on }\end{array}$} & \multirow{3}{*}{$\begin{array}{c}\text { Goal } \\
\text { Post } \\
\text { presentati } \\
\text { on }\end{array}$} & \multirow{3}{*}{ GOAL } & \\
\hline & & & & & & & & & & & & & & & & \multicolumn{3}{|c|}{$\begin{array}{l}\text { Evaluati } \\
\text { Follow-up Time \# } 1\end{array}$} & \multicolumn{3}{|c|}{ Follow-up Time \# 2} \\
\hline & & & & & & & $\begin{array}{l}\text { Baseline } \\
\text { (before } \\
\text { presentatio }\end{array}$ & $\begin{array}{c}\text { Post } \\
\text { presentati }\end{array}$ & & $\begin{array}{l}\text { Descri } \\
\text { ptive }\end{array}$ & $\begin{array}{l}\text { Wilcoxon } \\
\text { signed- }\end{array}$ & & & & & On & $\begin{array}{l}\text { At } \\
\text { Bick }\end{array}$ & In $T$ & $\begin{array}{l}\text { On } \\
\text { Targe }\end{array}$ & At & In \\
\hline 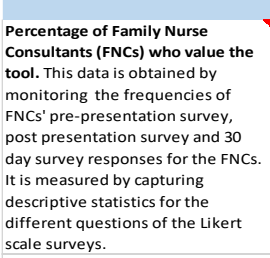 & $e^{e}$ & Process & Balancing & Financial & v & Contextual & n) & on & 30 days & $x$ & & & on & on & 30 days & Target & Risk & Danger, & $\mathrm{t}$ & Risk & Danger \\
\hline $\begin{array}{l}\text { Percentage of FNCS educated on } \\
\text { clinician-caregiver Communication } \\
\text { Form before implementing the } \\
\text { project. For a aiven period of time, } \\
\text { this is the number of FNCs } \\
\text { educted on the topic) / the total } \\
\text { number of FNCS who work at the } \\
\text { organization). All the FNCs were } \\
\text { educated on the communication } \\
\text { form. }\end{array}$ & & $x$ & & & $x$ & $\mathrm{x}$ & $x$ & $x$ & & & & & $0 \%$ & $100 \%$ & & $\mathrm{x}$ & & & & & \\
\hline $\begin{array}{l}\text { FNCs perception score of } \\
\text { useffulness of tool. This data is } \\
\text { obtained by monitoring the pre } \\
\text { and post survey responses for the } \\
\text { FNCs. It is measured by comparing } \\
\text { the medians pre and post } \\
\text { intervention. }\end{array}$ & $x$ & & & & $x$ & $\mathrm{x}$ & $x$ & $x$ & $x$ & & $x$ & $\begin{array}{l}\text { improved } \\
\text { FNCs' } \\
\text { perception of } \\
\text { value of tool }\end{array}$ & $3.5 / 4$ & $3.9 / 4$ & & $\mathrm{x}$ & & & & & \\
\hline $\begin{array}{l}\text { Percentage of FNCs who utilized } \\
\text { the communication tool. For a } \\
\text { given neriod of time, this is the } \\
\text { number of FNCS who reported } \\
\text { using the tool in their practice with } \\
\text { the caregiver) / (the totat number } \\
\text { of nurses who returned the } 30 \text { day } \\
\text { survey). }\end{array}$ & $x$ & $x$ & $x$ & & $x$ & & $x$ & & $x$ & $x$ & & $\begin{array}{l}\text { increased } \\
\text { utilization of } \\
\text { tool by the } \\
\text { FNCs with the } \\
\text { caregiver }\end{array}$ & $0 \%$ & $0 \%$ & $\geq 45 \%$ & & $\mathrm{x}$ & & & & \\
\hline $\begin{array}{l}\text { Financial cost for training FNCs. } \\
\text { This value accounts for the } \\
\text { estimated costs associated with } \\
\text { providing training to } 100 \% \text { of the } \\
\text { FNCs at the organization. The cost } \\
\text { is equal to the average hourly } \\
\text { selary multiplied by the hour of } \\
\text { training multiplied by the number } \\
\text { of staff ( } \$ 30 \text { per hour } x 1 \text { hour of } \\
\text { training, } X 8 \text { FNCS). Training cost to } \\
\text { be accounted once. }\end{array}$ & & & & $x$ & & & $x$ & & $\mathrm{x}$ & & & & $\begin{array}{l}\$ 240 \text { (a one- } \\
\text { time cost) }\end{array}$ & & $\$ 240$ & & & & & & \\
\hline $\begin{array}{l}\text { Average number of tools utilized } \\
\text { during the project. This value is } \\
\text { reportred by the FNCs in the } 30 \text { day } \\
\text { survey. }\end{array}$ & & $x$ & & & & & $x$ & $x$ & $x$ & $x$ & & $\begin{array}{l}\text { increased use } \\
\text { of the tool }\end{array}$ & 0 & 0 & 5 & & $\mathrm{x}$ & & & & \\
\hline $\begin{array}{l}\text { Percentage of caregivers who } \\
\text { benefited from the tool. This value } \\
\text { in correlated with the percentage } \\
\text { of FNCs who used the tool. The } \\
\text { FNCS who used the tool reported } \\
\text { that caregivers benefited from this } \\
\text { tool for their loved ones. }\end{array}$ & 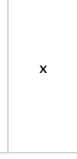 & & $x$ & & $\mathrm{x}$ & & $x$ & $x$ & $x$ & $x$ & & $\begin{array}{l}\text { caregiver } \\
\text { benefit of the } \\
\text { tool }\end{array}$ & $0 \%$ & $0 \%$ & $\geq 45 \%$ & & $\mathrm{x}$ & & & & \\
\hline
\end{tabular}




\section{Table 4}

Frequency Table for Ordinal Variables

\begin{tabular}{lrrr}
\hline Variable & $n$ & $\%$ & Cumulative $\%$ \\
\hline Pre_Q3 & 3 & 37.50 & 37.50 \\
Agree & 5 & 62.50 & 100.00 \\
Strongly Agree & 0 & 0.00 & 100.00 \\
Missing & & & \\
Pre_Q1 & 5 & 62.50 & 62.50 \\
Agree & 3 & 37.50 & 100.00 \\
Strongly Agree & 0 & 0.00 & 100.00 \\
Missing & & & \\
Pre_Q4 & 1 & 12.50 & 12.50 \\
Disagree & 4 & 50.00 & 62.50 \\
Agree & 3 & 37.50 & 100.00 \\
Strongly Agree & 0 & 0.00 & 100.00 \\
Missing & & & \\
Pre_Q2 & 1 & 12.50 & 12.50 \\
Agree & 7 & 87.50 & 100.00 \\
Strongly Agree & 0 & 0.00 & 100.00 \\
Missing & & & \\
Pre_Q5 & 5 & 62.50 & 62.50 \\
Agree & 3 & 37.50 & 100.00 \\
Strongly Agree & 0 & 0.00 & 100.00 \\
Missing & & & \\
\hline
\end{tabular}




\section{Table 5}

Frequency Table for Ordinal Variables

\begin{tabular}{lrrr}
\hline Variable & $n$ & $\%$ & Cumulative $\%$ \\
\hline Post_Q1 & 1 & 12.50 & 12.50 \\
Agree & 7 & 87.50 & 100.00 \\
Strongly Agree & 0 & 0.00 & 100.00 \\
Missing & & & \\
Post_Q2 & 2 & 25.00 & 25.00 \\
Agree & 6 & 75.00 & 100.00 \\
Strongly Agree & 0 & 0.00 & 100.00 \\
Missing & & & \\
Post_Q5 & 1 & 12.50 & 12.50 \\
Agree & 7 & 87.50 & 100.00 \\
Strongly Agree & 0 & 0.00 & 100.00 \\
Missing & & & \\
Post_Q4 & 3 & 37.50 & 100.00 \\
Agree & 37.50 \\
Strongly Agree & 5 & 62.50 & 100.00 \\
Missing & 0 & 0.00 & 12.50 \\
Post_Q3 & & & 100.00 \\
Agree & 1 & 12.50 & 100.00 \\
Strongly Agree & 7 & 87.50 & \\
Missing & 0 & 0.00 &
\end{tabular}

Note. Due to rounding errors, percentages may not equal $100 \%$. 


\section{Table 6}

Frequency Table for Nominal and Ordinal Variables

\begin{tabular}{llr}
\hline Variable & $n$ & $\%$ \\
\hline Q1_Post_30_days & & \\
Strongly Agree & 3 & 42.86 \\
Agree & 1 & 14.29 \\
Disagree & 2 & 28.57 \\
Strongly Disagree & 1 & 14.29 \\
Q2_Post_30_days & & \\
Strongly Agree & 5 & 71.43 \\
Agree & 2 & 28.57 \\
Q3_Post_30_days & & \\
Strongly Agree & 6 & 85.71 \\
Agree & 1 & 14.29 \\
Q4_Post_30_days & & \\
Strongly Agree & 6 & 85.71 \\
Agree & 1 & 14.29 \\
Q5_Post_30_days_Nominal & & \\
3 & 1 & 14.29 \\
1 & 2 & 28.57 \\
0 & 4 & 57.14 \\
\hline
\end{tabular}

Note. Due to rounding errors, percentages may not equal $100 \%$. 


\section{Table 7}

Summary Statistics Table for Interval and Ratio Variables

\begin{tabular}{lrrr}
\hline Variable & $M$ & $S D$ & $n$ \\
\hline Q5_Post_30_days & 0.71 & 1.11 & 7 \\
\hline
\end{tabular}




\section{Figure 1}

\section{PRISMA Model}

\section{PRISMA 2009 Flow Diagram}
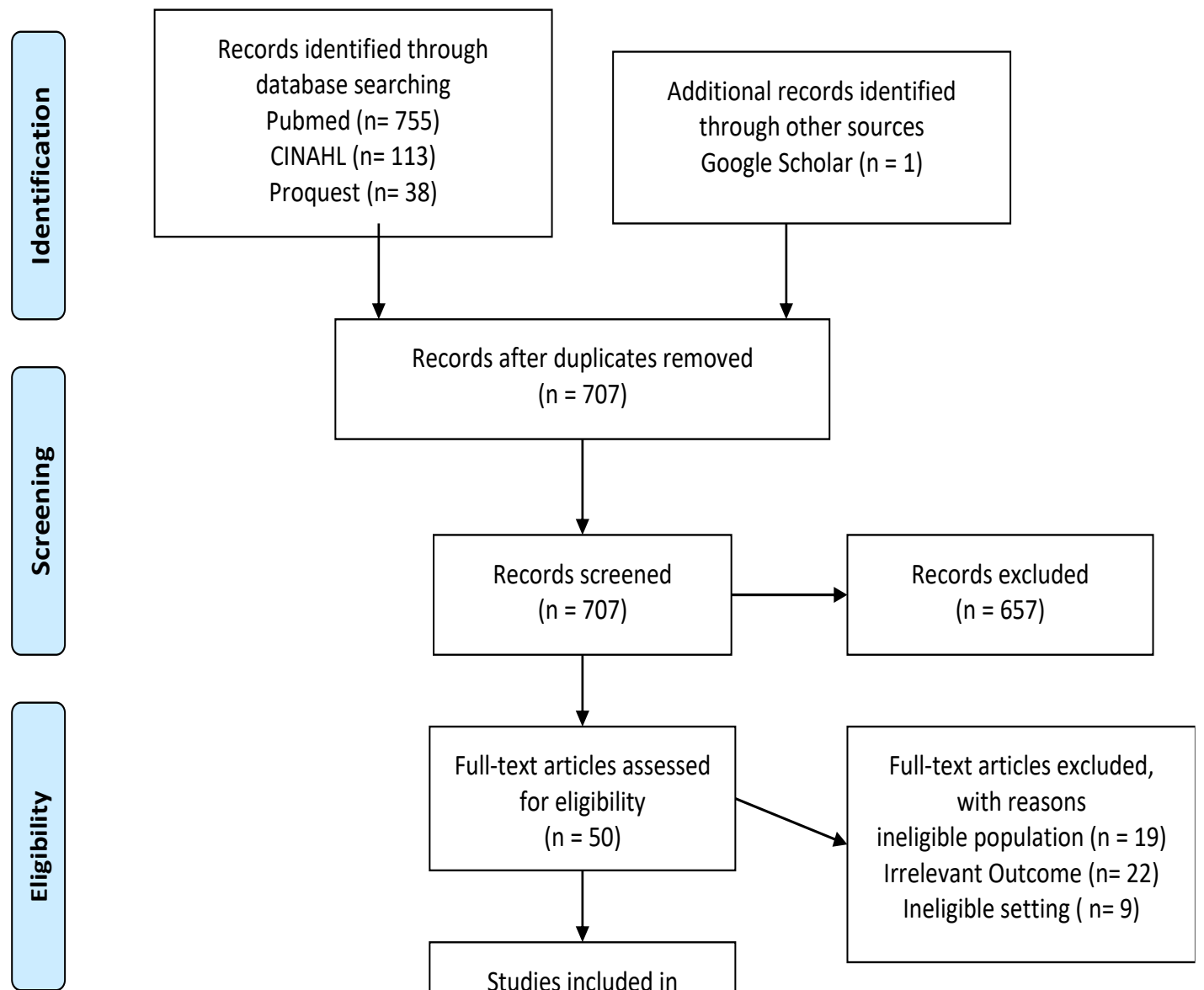

Studies included in qualitative synthesis $(n=0)$

Studies included in quantitative synthesis (meta-analysis)

$$
(n=10)
$$




\section{Figure 2}

Ranked Values of Pre.Q.Overall and Post.Test.Overall

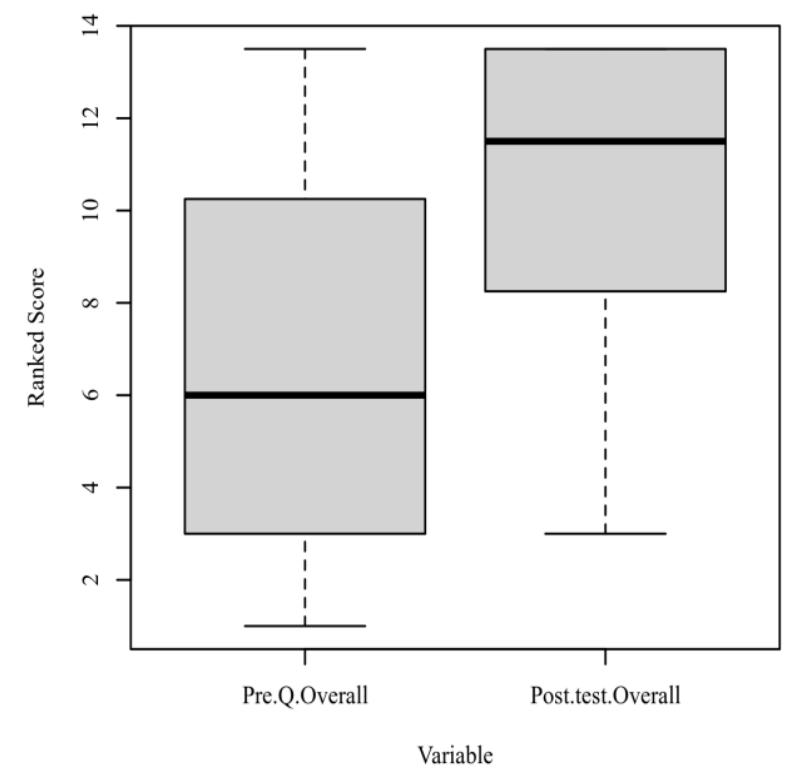




\section{Appendix A}

Summary of Primary Research Evidence

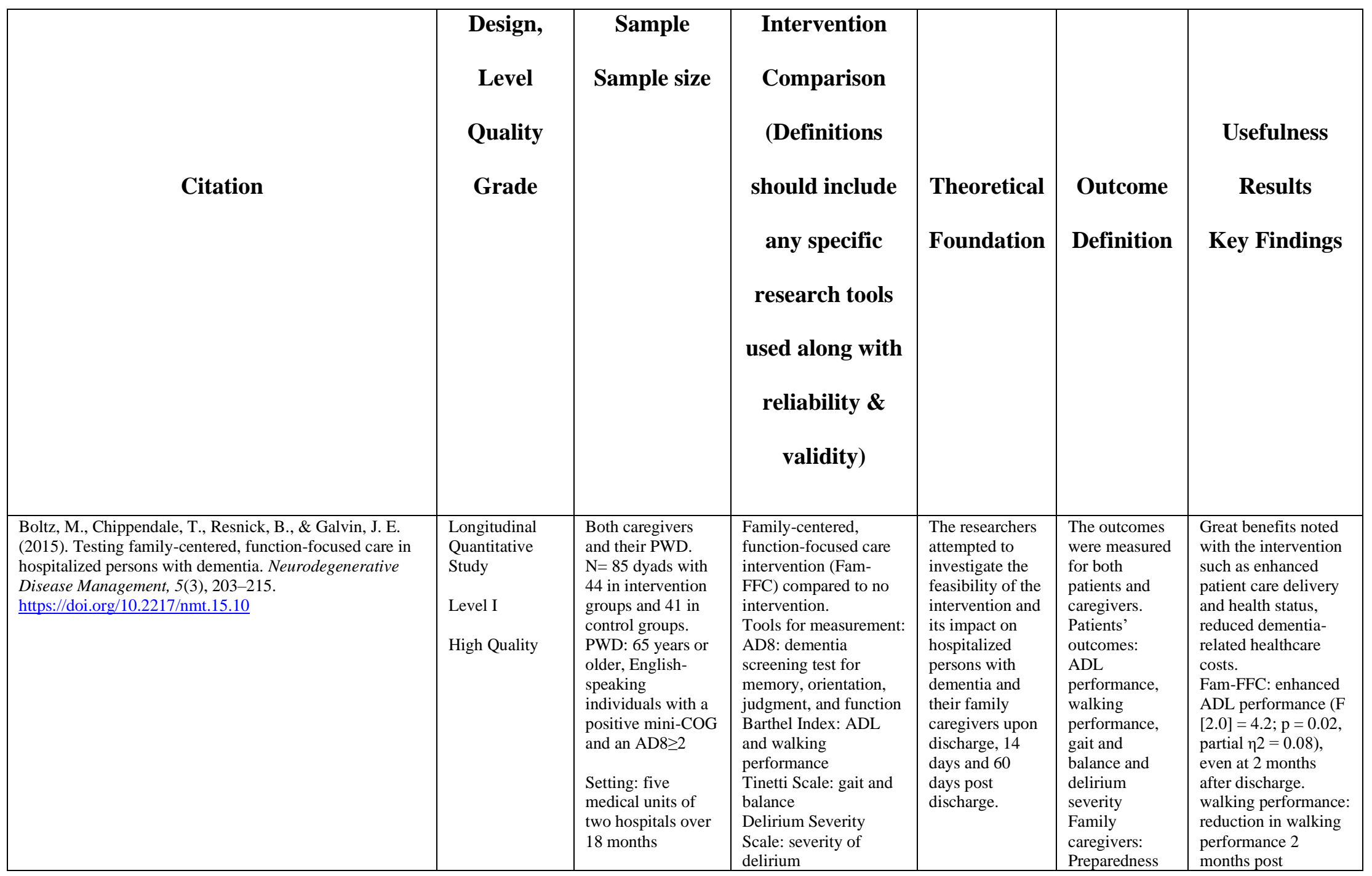




\begin{tabular}{|c|c|c|c|c|c|c|}
\hline & & $\begin{array}{l}\text { Hospital 1: } \\
\text { 1Intervention Unit } \\
\text { (IU) and 2Control } \\
\text { Units (CU) } \\
\text { Hospital 2: 1IU } \\
\text { and 1CU }\end{array}$ & $\begin{array}{l}\text { Preparedness for } \\
\text { Caregiving Scale: } \\
\text { caregivers' level of } \\
\text { preparedness to render } \\
\text { care to person with } \\
\text { dementia } \\
\text { Hospital Anxiety and } \\
\text { Depression Scale } \\
\text { (HADS): anxiety and } \\
\text { depression among } \\
\text { caregivers } \\
\text { Mutuality Scale: } \\
\text { relationship among the } \\
\text { dyad } \\
\text { Caregiver Strain Index: } \\
\text { strains in caregivers } \\
\text { 'lives }\end{array}$ & & $\begin{array}{l}\text { for caregiving, } \\
\text { anxiety, } \\
\text { depression, role } \\
\text { strain, } \\
\text { mutuality }\end{array}$ & $\begin{array}{l}\text { discharges }(\mathrm{F}[2.5]= \\
6.1 ; \mathrm{p}=0.001, \text { partial } \\
\eta 2=0.11) \\
\text { significant decrease } \\
\text { in overall delirium } \\
\text { severity (F }[1.4]= \\
4.1 ; \mathrm{p}=0.03 \text {, partial } \\
\eta 2=0.08) \text {. } \\
\text { significant decrease } \\
\text { in delirium severity } \\
(\mathrm{F}[1.4]=4.1 ; \mathrm{p}= \\
0.03, \text { partial } \eta 2= \\
0.08) \text {. Results } \\
\text { sustained } 2 \text { months } \\
\text { post discharge. } \\
\text { Decreased } \\
\text { readmission rate } \\
\text { Family caregivers: } \\
\text { significant increase in } \\
\text { preparedness for } \\
\text { caregiving and less } \\
\text { anxiety with } \mathrm{P}<0.04\end{array}$ \\
\hline $\begin{array}{l}\text { Isaac, L. M., Buggy, E., Sharma, A., Karberis, A., } \\
\text { Maddock, K. M., \& Weston, K. M. (2018). Enhancing } \\
\text { hospital care of patients with cognitive impairment. } \\
\text { International Journal of Health Care Quality Assurance } \\
\text { 31(2), 173-186. } \\
\text { https://doi.org/10.1108/IJHCQA-11-2016-0173 }\end{array}$ & $\begin{array}{l}\text { Mixed Study } \\
\text { Design } \\
\text { Level II } \\
\text { Good Quality }\end{array}$ & $\begin{array}{l}\text { Cognitively } \\
\text { impaired } \\
\text { individuals over } \\
\text { age 70, admitted to } \\
\text { Wards A and B } \\
\text { throughout the } \\
\text { three study phases. } \\
\text { Baseline phase: n } \\
=689 \text {. } \\
\text { pilot phase: } n= \\
\text { 697; establishment } \\
\text { phase: } n=661 \\
\text { Informal carers: } n= \\
43 \\
\text { Hospital staff: } \\
\text { nurses }\end{array}$ & $\begin{array}{l}\text { A total of } 44 \text { separate } \\
\text { education sessions } \\
\text { offered to the } \\
\text { multidisciplinary team } \\
\text { (i.e., nursing, allied } \\
\text { health, and medical } \\
\text { staff) over an eight- } \\
\text { month period during } \\
\text { the baseline data } \\
\text { collection phase. Also, } \\
30 \text { TOP5 education } \\
\text { sessions provided to } \\
\text { staff on both Wards A } \\
\text { and B during the pilot } \\
\text { phase. } \\
\text { Surveys for informal } \\
\text { caregivers completed } \\
\text { during pilot phase. } \\
\text { nurses completed } \\
\text { surveys at baseline, } \\
\text { pilot, and } \\
\text { implementation phases. } \\
\text { Baseline phase: normal } \\
\text { care }\end{array}$ & $\begin{array}{l}\text { The authors aim } \\
\text { to investigate } \\
\text { whether the } \\
\text { involvement of } \\
\text { TOP5 initiative } \\
\text { could improve } \\
\text { patient care and } \\
\text { healthcare } \\
\text { delivery for } \\
\text { cognitively } \\
\text { impaired } \\
\text { patients. }\end{array}$ & $\begin{array}{l}\text { Outcome } \\
\text { measures } \\
\text { include a } \\
\text { reduced } \\
\text { number of } \\
\text { falls, number } \\
\text { of patients } \\
\text { allocated } \\
\text { "specials", and } \\
\text { LOS }\end{array}$ & $\begin{array}{l}\text { The implementation } \\
\text { of TOP5 initiative led } \\
\text { to a significant } \\
\text { reduction in the } \\
\text { number of falls and } \\
\text { the utilization of } \\
\text { "specials" needed to } \\
\text { provide one on one } \\
\text { supervision for } \\
\text { cognitively impaired } \\
\text { patients. } \\
\text { With TOP5, 27\% } \\
\text { reduction in average } \\
\text { number of falls } \\
\text { between baseline and } \\
\text { the pilot phase; and a } \\
45 \% \text { reduction } \\
\text { between } \\
\text { baseline and the } \\
\text { establishment phase } \\
\text { were noted. } \\
\text { Statistical } \\
\text { significance with } \\
p<0.05 \text { for the } \\
\text { reduction in the } \\
\text { number of falls for } \\
\text { both wards between }\end{array}$ \\
\hline
\end{tabular}




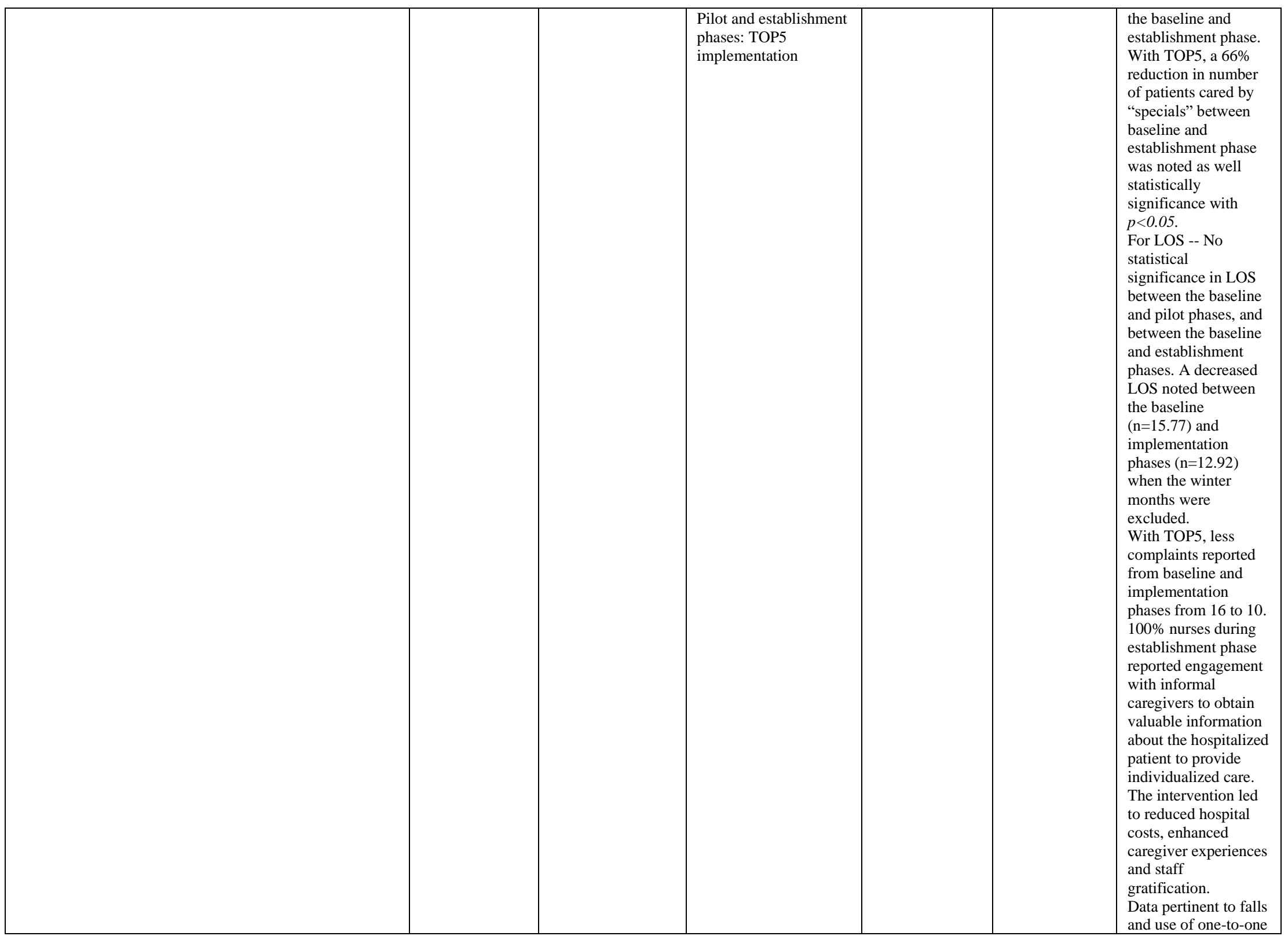




\begin{tabular}{|c|c|c|c|c|c|c|}
\hline & & & & & & $\begin{array}{l}\text { nursing personnel } \\
\text { over the study period } \\
\text { was retrieved from } \\
\text { the organization's } \\
\text { current incident } \\
\text { information } \\
\text { management system. }\end{array}$ \\
\hline $\begin{array}{l}\text { Kelley, L. S., Specht, J. K. P., \& Maas, M. L. (2000). } \\
\text { Family involvement in care for individuals with dementia } \\
\text { protocol. Journal of Gerontological Nursing, 26(2), 13-21. } \\
\text { https://prx- } \\
\text { usa.lirn.net/login?url=https://www.proquest.com/scholarly- } \\
\text { journals/family-involvement-care-individuals-with- } \\
\text { dementia/docview/204190834/se-2?accountid=158603 }\end{array}$ & $\begin{array}{l}\text { Review Article } \\
\text { Level III } \\
\text { Good Quality }\end{array}$ & $\begin{array}{l}\text { Many articles } \\
\text { reviewed to } \\
\text { provide a synthesis } \\
\text { on the FIC } \\
\text { protocol that can } \\
\text { be effective for } \\
\text { positive outcomes }\end{array}$ & $\begin{array}{l}\text { FIC implementation } \\
\text { across healthcare } \\
\text { settings. } \\
4 \text { phases of the FIC: } \\
\text { Orientation/Assessment } \\
\text { Education of both } \\
\text { informal caregivers and } \\
\text { facility providers } \\
\text { Negotiation and } \\
\text { partnership } \\
\text { Evaluation }\end{array}$ & $\begin{array}{l}\text { The authors } \\
\text { present a } \\
\text { description of } \\
\text { the intervention, } \\
\text { the different } \\
\text { healthcare } \\
\text { settings it can be } \\
\text { implemented, } \\
\text { and how both } \\
\text { the informal } \\
\text { caregivers and } \\
\text { staff should } \\
\text { collaborate for } \\
\text { the intervention } \\
\text { to lead to } \\
\text { fruition. }\end{array}$ & $\begin{array}{l}\text { Outcome } \\
\text { measures } \\
\text { include the FIC } \\
\text { Process and } \\
\text { Outcomes } \\
\text { Monitor (to } \\
\text { capture family } \\
\text { gratification } \\
\text { with the } \\
\text { relationship } \\
\text { and the quality } \\
\text { of care } \\
\text { rendered to the } \\
\text { PWD) and FIC } \\
\text { Nursing } \\
\text { Outcomes and } \\
\text { Classification } \\
\text { Monitor (to } \\
\text { determine if } \\
\text { anticipated } \\
\text { outcomes for } \\
\text { PWD being } \\
\text { met) }\end{array}$ & $\begin{array}{l}\text { Communication is } \\
\text { vital between partners } \\
\text { for FIC success. } \\
\text { Both family/informal } \\
\text { caregivers and } \\
\text { facility providers } \\
\text { agree to participate in } \\
\text { the planning, } \\
\text { provision, and } \\
\text { coordination of care } \\
\text { for the PWD in the } \\
\text { healthcare setting. } \\
\text { Regardless of the } \\
\text { setting, partners will } \\
\text { need to re-evaluate } \\
\text { the needs of PWD } \\
\text { and renegotiate the } \\
\text { outcomes to monitor } \\
\text { for progress for the } \\
\text { anticipated length of } \\
\text { time } \\
\text { FIC can be beneficial } \\
\text { for both the PWD and } \\
\text { the family caregivers }\end{array}$ \\
\hline $\begin{array}{l}\text { Li, H., Melnyk, B.M., Mccann, R., Chatcheydang, J., } \\
\text { Koulouglioti, C., Nichols, L.W., Lee, M.-D., Ghassemi, A. } \\
\text { (2003). Creating avenues for relative empowerment } \\
\text { (CARE): A pilot test of an intervention to improve } \\
\text { outcomes of hospitalized elders and family caregivers. } \\
\text { Research in Nursing \& Health 26, 284-299. } \\
\text { https://doi.org/10.1002/nur.10091 }\end{array}$ & $\begin{array}{l}\text { Randomized } \\
\text { Controlled Trial } \\
\text { Level I } \\
\text { High Quality }\end{array}$ & $\begin{array}{l}\text { Participants: } \\
\text { Family caregivers } \\
\text { of hospitalized } \\
\text { elders. } \\
\text { CARE program } \\
\text { with } \mathrm{N}=25 \text { and } \\
\text { comparison group } \\
\text { with } \mathrm{N}=24\end{array}$ & $\begin{array}{l}\text { CARE program -- } \\
\text { Phase I audiotape: } \\
\text { information about } \\
\text { emotional responses } \\
\text { and specific caregiving } \\
\text { strategies to disrupt } \\
\text { inappropriate } \\
\text { behaviors. } \\
\text { Phase II audiotape: } \\
\text { reinforcement of the } \\
\text { Phase I content } \\
\text { audiotape } \\
\text { With CARE program, } \\
\text { family caregivers agree } \\
\text { to be involved in the } \\
\text { elder's care during } \\
\text { hospitalization }\end{array}$ & $\begin{array}{l}\text { The authors } \\
\text { attempted to } \\
\text { investigate if } \\
\text { effects of the } \\
\text { CARE program } \\
\text { were positive } \\
\text { on the outcomes } \\
\text { of both elderly } \\
\text { patients and } \\
\text { their family } \\
\text { caregivers } \\
\text { during and } \\
\text { after } \\
\text { hospitalization }\end{array}$ & $\begin{array}{l}\text { The outcomes } \\
\text { measures } \\
\text { include im- } \\
\text { proved } \\
\text { cognitive and } \\
\text { depressive } \\
\text { symptoms for } \\
\text { patients with } \\
\text { dementia both } \\
\text { during and } \\
\text { after } \\
\text { hospitalization, } \\
\text { ability to } \\
\text { understand, } \\
\text { interpret, and } \\
\text { predict their } \\
\text { elders 'their } \\
\text { loved ones }\end{array}$ & $\begin{array}{l}\text { CARE family } \\
\text { caregivers reporting } \\
\text { lower depressive } \\
\text { symptoms( }<.01 \text { ) and } \\
\text { higher mutuality } \\
(\mathrm{p}<.05) \text { than } \\
\text { comparison group. } \\
\text { CARE group: } \\
\text { significantly lower } \\
\text { acute confusion rate } \\
\text { (p<0.04), less days } \\
\text { suffering from } \\
\text { urinary } \\
\text { incontinence }(\mathrm{p}<0.07) \text {, } \\
\text { less incidents of fecal } \\
\text { incontinence } \\
\text { (p<0.02), and fewer } \\
\text { readmission rate at } 2 \\
\end{array}$ \\
\hline
\end{tabular}




\begin{tabular}{|c|c|c|c|c|c|c|}
\hline & & & $\begin{array}{l}\text { Comparison group - } \\
\text { Phase I and II: contains } \\
\text { information about the } \\
\text { hospital services and } \\
\text { policies. } \\
\text { Data collection tools: } \\
\text { STAI: family } \\
\text { caregiver' anxiety } \\
\text { FWS: family worry } \\
\text { FCAI: types of care } \\
\text { FPS: family } \\
\text { preparedness } \\
\text { FRRS: role rewards } \\
\text { Lack of Resources } \\
\text { Scale FLRS: role strain } \\
\text { Global Strain Scale } \\
\text { FGSS: global strain }\end{array}$ & & $\begin{array}{l}\text { behaviors and } \\
\text { the ability to } \\
\text { care for them, } \\
\text { decreased } \\
\text { confusion rates } \\
\text { during } \\
\text { hospitalization; } \\
\text { and reduction, } \\
\text { of caregivers' } \\
\text { depressive } \\
\text { symptoms } \\
\text { during } \\
\text { hospitalization }\end{array}$ & $\begin{array}{l}\text { weeks and } 2 \text { months } \\
\text { post discharge } \\
\text { ( }<<0.08 \text { ) than for } \\
\text { comparison group } \\
\text { Significant role } \\
\text { rewards ( }<0.04) \\
\text { than comparison } \\
\text { caregivers at } 2 \text { weeks } \\
\text { after hospital } \\
\text { discharge } \\
\text { Higher scores on } \\
\text { mutuality between } \\
\text { caregivers and } \\
\text { persons with } \\
\text { dementia during and } \\
\text { after hospitalization } \\
\text { ( }<0.01 \text { ) than } \\
\text { comparison } \\
\text { caregivers. } \\
\text { No significant } \\
\text { differences between } \\
\text { the study groups on } \\
\text { caregivers' emotional } \\
\text { outcomes, role } \\
\text { adaptation, } \\
\text { preparedness for } \\
\text { follow-up care, and } \\
\text { role strain during and } \\
\text { after hospitalization }\end{array}$ \\
\hline $\begin{array}{l}\text { Luxford, K., Axam, A., Hasnip, F., Dobrohotoff, J., } \\
\text { Strudwick, M., Reeve, R., Hou, C., \& Viney, R. (2015). } \\
\text { Improving clinician-carer communication for safer } \\
\text { hospital care: a study of the 'TOP 5'strategy in patients } \\
\text { with dementia. International Journal for Quality in Health } \\
\text { Care, 27(3), 175-182. } \\
\text { https://doi.org/10.1093/intghc/mzv026 }\end{array}$ & $\begin{array}{l}\text { Pre/Post Study } \\
\text { Design } \\
\text { Level II } \\
\text { High Quality }\end{array}$ & $\begin{array}{l}\mathrm{N}=53 \text { wards } \\
\text { medical, of } 22 \\
\text { hospitals were } \\
\text { involved in the } \\
\text { study } \\
\text { Champion team at } \\
\text { each hospital } \\
2 \text { wards in one } \\
\text { hospital to monitor } \\
\text { fall rate and } \\
\text { antipsychotic drugs } \\
\text { with TOP5 } \\
\text { implementation }\end{array}$ & $\begin{array}{l}\text { TOP } 5 \text { intervention } \\
\text { compared to standard } \\
\text { care } \\
\text { Data collection tools: } \\
\text { Likert-scale surveys for } \\
\text { hospital providers and } \\
\text { completed pre- } \\
\text { implementation of the } \\
\text { tool, at } 6 \text { months and } \\
12 \text { months } \\
\text { Liker-scale surveys for } \\
\text { caregivers to be } \\
\text { completed during the } \\
12 \text {-month period } \\
\text { (hospital stay or time of } \\
\text { discharge) } \\
\text { For fall monitoring: } \\
\text { Data captured } 12 \\
\text { months prior and } 12 \\
\text { months during }\end{array}$ & $\begin{array}{l}\text { The authors } \\
\text { attempt to } \\
\text { investigate if the } \\
\text { implementation } \\
\text { of "TOP 5" can } \\
\text { enhance safety } \\
\text { for persons with } \\
\text { dementia in the } \\
\text { acute care } \\
\text { setting and its } \\
\text { impact on both } \\
\text { hospital } \\
\text { providers and } \\
\text { informal/family } \\
\text { caregivers. }\end{array}$ & $\begin{array}{l}\text { Outcome } \\
\text { measures } \\
\text { include } \\
\text { hospital } \\
\text { providers and } \\
\text { informal } \\
\text { caregivers' } \\
\text { perceptions, } \\
\text { safety } \\
\text { measures such } \\
\text { reported falls } \\
\text { and usage of } \\
\text { non-regular } \\
\text { anti- } \\
\text { psychotics), } \\
\text { resource use } \\
\text { and costs. }\end{array}$ & $\begin{array}{l}\text { On average } 6 \text { TOP5s } \\
\text { interventions were } \\
\text { conducted monthly } \\
\text { by each hospital } \\
\text { Increased utilization } \\
\text { rate of TOP } 5 \\
\text { implementation } \\
\text { throughout the study } \\
\text { from an average of } \\
23 \% \text { to } 64 \% \text { at the } \\
\text { end of the } \\
\text { implementation } \\
\text { period. } \\
\text { For clinicians, higher } \\
\text { level of confidence } \\
\text { post introduction of } \\
\text { TOP } 5 \text { with (M=3.22, } \\
\text { SD = 0.66) compared } \\
\text { to data collected pre- } \\
\text { implementation }\end{array}$ \\
\hline
\end{tabular}




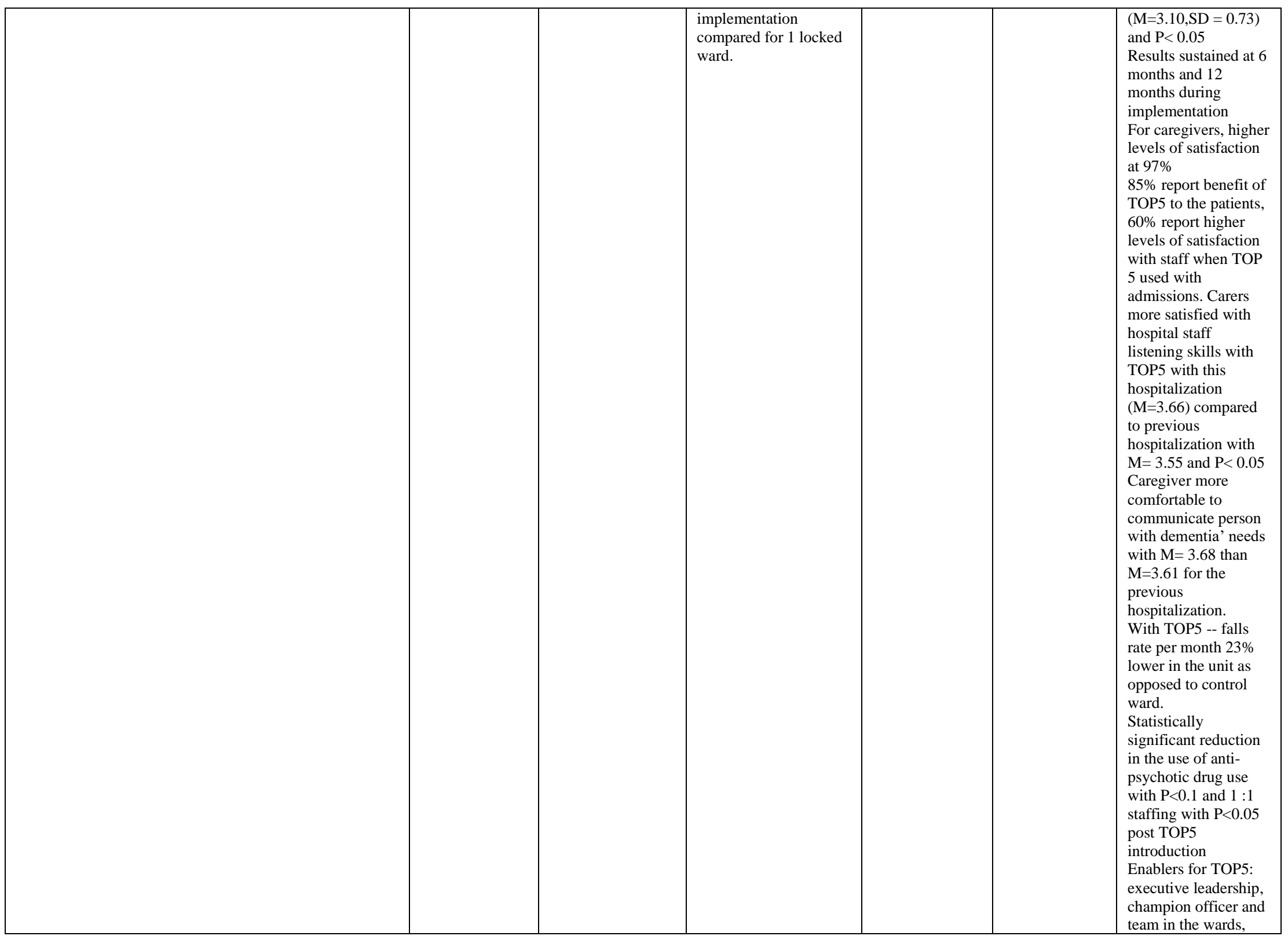




\begin{tabular}{|c|c|c|c|c|c|c|}
\hline & & & & & & $\begin{array}{l}\text { interprofessional } \\
\text { involvement, } \\
\text { education of hospital } \\
\text { staff in the acute } \\
\text { ward about dementia } \\
\text { and ability to engage } \\
\text { in conversations with } \\
\text { informal caregivers. }\end{array}$ \\
\hline $\begin{array}{l}\text { Rosenbloom-Brunton, D. A., Henneman, E. A., \& Inouye, } \\
\text { S. K. (2010). Feasibility of family participation in a } \\
\text { delirium prevention program for hospitalized older adults. } \\
\text { Journal of Gerontological Nursing, 36(9), 22-33. } \\
\text { http://dx.doi.org/10.3928/00989134-20100330-02 }\end{array}$ & $\begin{array}{l}\text { Exploratory } \\
\text { Study } \\
\text { Level II } \\
\text { Good Quality }\end{array}$ & $\begin{array}{l}\text { Convenience } \\
\text { sample of English- } \\
\text { speaking family } \\
\text { caregivers of } \\
\text { hospitalized adults, } \\
65 \\
\text { and older, with one } \\
\text { risk factor of } \\
\text { delirium } \\
\mathrm{N}=15 \text { family } \\
\text { caregivers and } \mathrm{N}= \\
15 \text { patients } \\
85 \% \text { patients }-2 / 4 \\
\text { delirium associated } \\
\text { risk factors and } \\
69 \% \text {-- } 3 \text { or } 4 \text { risk } \\
\text { factors }\end{array}$ & $\begin{array}{l}\text { Family-HELP } \\
\text { implementation. } \\
\text { Family caregivers to } \\
\text { use the standardized } \\
\text { Family Caregiver } \\
\text { Tracking } \\
\text { Form to document the } \\
\text { daily frequency of } \\
\text { The intervention } \\
\text { completion and reasons } \\
\text { for not completing it } \\
\text { MMSE - cognitive } \\
\text { impairment } \\
\text { Katz Index of } \\
\text { Independence } \\
\text { in Activities of Daily } \\
\text { Living - ADL } \\
\text { impairment } \\
\text { Standard bedside } \\
\text { Jaeger test - vison } \\
\text { impairment } \\
\text { Whisper test-hearing } \\
\text { impairment } \\
\text { Nurse questionnaires }\end{array}$ & $\begin{array}{l}\text { The Calgary } \\
\text { Family } \\
\text { Intervention } \\
\text { Model is used in } \\
\text { the study to } \\
\text { investigate if the } \\
\text { partnership of } \\
\text { the nurse with } \\
\text { family caregiver } \\
\text { can improve the } \\
\text { care of the } \\
\text { patient with } \\
\text { delirium in the } \\
\text { acute care } \\
\text { setting }\end{array}$ & $\begin{array}{l}\text { No patient } \\
\text { developed } \\
\text { delirium with } \\
\text { the } \\
\text { implementation } \\
\text { of Family -- } \\
\text { HELP }\end{array}$ & $\begin{array}{l}\text { Family members } \\
\text { must be actively } \\
\text { engaged in the } \\
\text { process for HELP } \\
\text { model to be feasible. } \\
\text { staff } \\
\text { Nurses must be } \\
\text { educated on the risk } \\
\text { factors of delirium, } \\
\text { its clinical } \\
\text { presentation, } \\
\text { strategies to prevent } \\
\text { it as well as ways to } \\
\text { partner with family } \\
\text { caregivers. } \\
\text { Hospital staff to } \\
\text { facilitate the } \\
\text { communication } \\
\text { process for family } \\
\text { caregivers to } \\
\text { participate in the } \\
\text { program } \\
\text { Championing of the } \\
\text { intervention through } \\
\text { the display of posters } \\
\text { on all units } \\
\text { Cannot generalize the } \\
\text { results due to the } \\
\text { small sample }\end{array}$ \\
\hline $\begin{array}{l}\text { Sampson, E. L., Vickerstaff, V., Lietz, S., \& Orrell, M. } \\
\text { (2017). Improving the care of people with dementia in } \\
\text { general hospitals: evaluation of a whole-system train-the- } \\
\text { trainer model. International Psychogeriatrics, 29(4), 605- } \\
\text { 614. https://doi.org/10.1017/S1041610216002222 }\end{array}$ & $\begin{array}{l}\text { Mixed Study } \\
\text { Design } \\
\text { Level II } \\
\text { Good Quality }\end{array}$ & $\begin{array}{l}\text { Study setting: eight } \\
\text { acute hospital } \\
\text { trusts in London } \\
\text { via a large } \\
\text { academic health } \\
\text { and science } \\
\text { network. English- } \\
\text { Participants with N } \\
=2020 \text { staff pre- } \\
\text { training } \\
\text { questionnaire with } \\
81 \% \text { females and } \\
\text { with } 5 \text { years of }\end{array}$ & $\begin{array}{l}\text { "Whole system train } \\
\text { the trainer Model" } \\
\text { Data collection tools: } \\
\text { "Sense of Competence } \\
\text { in Dementia Care" } \\
\text { (SCIDS) - individual } \\
\text { level } \\
\text { Person Interaction and } \\
\text { Environment (PIE) } \\
\text { Use of specific tools, } \\
\text { i.e. "This Is Me," } \\
\text { Numbers and types of } \\
\text { staff trained per trust. }\end{array}$ & $\begin{array}{l}\text { The authors } \\
\text { attempted to } \\
\text { assess whether a } \\
\text { whole system } \\
\text { train the trainer } \\
\text { model could } \\
\text { enhance the } \\
\text { provision of care } \\
\text { for dementia } \\
\text { patients in the } \\
\text { hospital. }\end{array}$ & $\begin{array}{l}\text { The outcome } \\
\text { measures } \\
\text { include } \\
\text { enhanced } \\
\text { interaction with } \\
\text { the patient, } \\
\text { knowledge of } \\
\text { the } \\
\text { environment } \\
\text { and the patient } \\
\text { as an individual } \\
\text { to participate } \\
\text { his care. Other }\end{array}$ & $\begin{array}{l}\text { The study revealed } \\
\text { increased level of } \\
\text { competence } \\
\text { especially for } \\
\text { building relationships } \\
\text { from mean } 8.5 \text { pre- } \\
\text { training and } 11.1 \text { post } \\
\text { training. } \\
\text { Mean SCID score } \\
\text { was } 43.2 \text { at baseline } \\
\text { and } 50.7 \text { at 3-month } \\
\text { follow-up }\end{array}$ \\
\hline
\end{tabular}




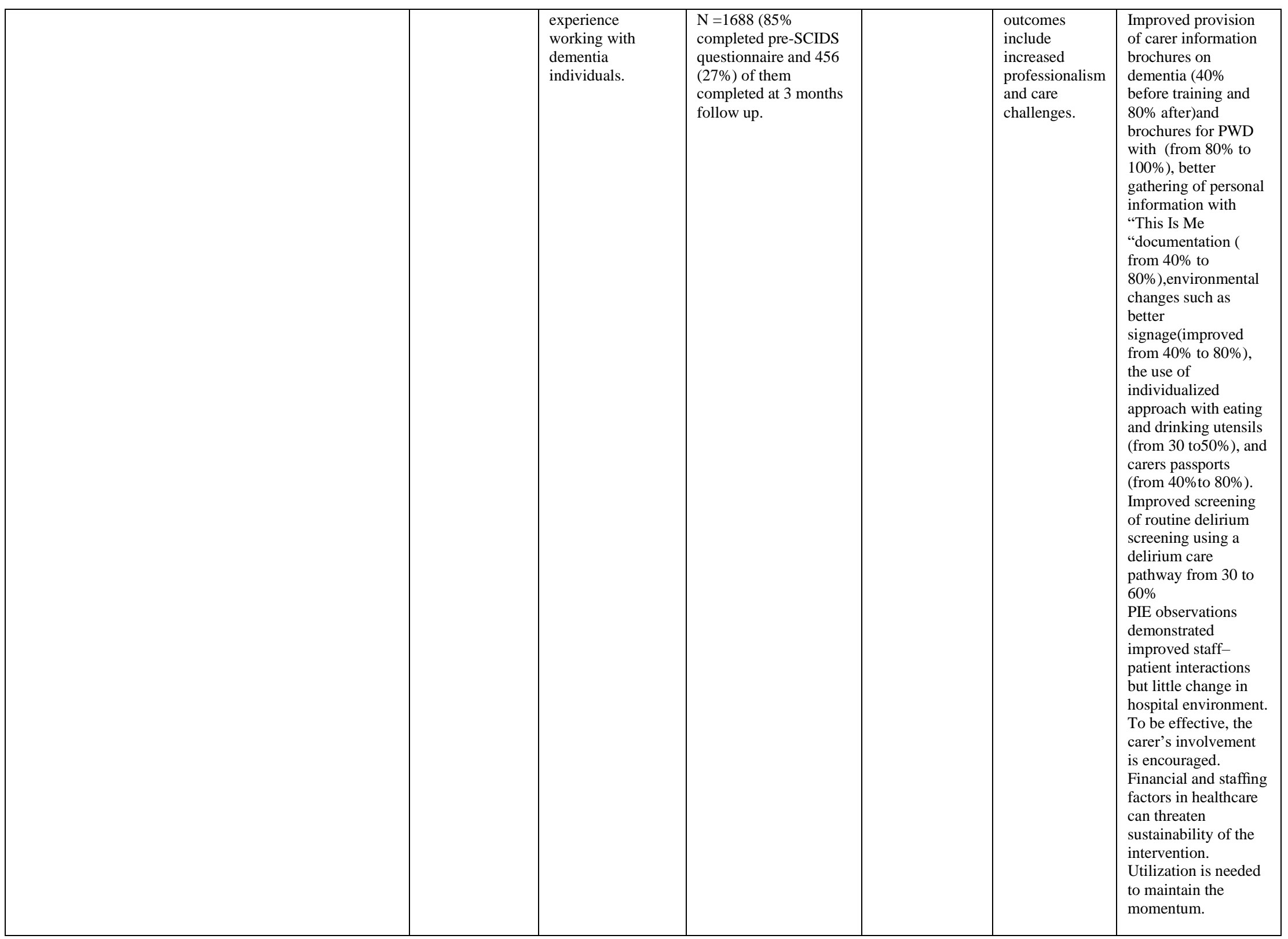




\section{Legend:}

ADL: Activity of Daily Living BDI-II: Beck Depression Scale FCAI: Family Care Actions Index FGSS: Global Strain Scale

FIC: Family Involvement in Care

FLPS: Lack of Resources $\mathrm{Scale}$

FLRS: Lack of Resources Scale

FPS: Family Preparedness Scale

FWS: Family Worry Scale

LOS: Length of stay

PWD: Person with Dementia

STAI: State-Trait Anxiety Inventory 


\section{Appendix B}

\section{Summary of Systematic Reviews}

\begin{tabular}{|c|c|c|c|c|c|c|c|}
\hline Citation & $\begin{array}{l}\text { Quality } \\
\text { Grade }\end{array}$ & Question & Search Strategy & $\begin{array}{l}\text { Inclusion/ } \\
\text { Exclusion Criteria }\end{array}$ & $\begin{array}{l}\text { Data Extraction } \\
\text { and Analysis }\end{array}$ & Key Findings & $\begin{array}{l}\text { Usefulness/Reco } \\
\text { mmendation/ } \\
\text { Implications }\end{array}$ \\
\hline $\begin{array}{l}\text { Beardon, S., } \\
\text { Patel, K., } \\
\text { Davies, B., \& } \\
\text { Ward, H. } \\
\text { (2018). } \\
\text { Informal carers' } \\
\text { perspectives on } \\
\text { the delivery of } \\
\text { acute hospital } \\
\text { care for patients } \\
\text { with dementia: } \\
\text { a systematic } \\
\text { review. BMC } \\
\text { Geriatrics, } \\
\text { 18(1), 1-11. } \\
\text { https://bmcgeri } \\
\text { atr.biomedcentr } \\
\text { al.com/articles/ } \\
10.1186 / \mathrm{s} 12877 \\
-018-0710-\mathrm{x} \\
\end{array}$ & $\begin{array}{l}\text { Systematic } \\
\text { Review } \\
\text { Level I } \\
\text { Good } \\
\text { Quality } \\
\\
\\
\end{array}$ & $\begin{array}{l}\text { Q1-What is the effect } \\
\text { of caregivers' } \\
\text { perspectives on the } \\
\text { delivery of care for } \\
\text { persons with dementia } \\
\text { in the acute care } \\
\text { hospital? } \\
\text { Q2--- Does using } \\
\text { person-centered } \\
\text { approaches enhance the } \\
\text { experience of an } \\
\text { admission for both } \\
\text { caregivers and patient? }\end{array}$ & \begin{tabular}{|l} 
Medline, Embase, \\
Health Management \\
Information \\
Consortium, and \\
PsycINFO, Google \\
Scholar were searched \\
for the evidence \\
\\
\end{tabular} & \begin{tabular}{|l|} 
Eligibility criteria included \\
studies where the care was \\
delivered in the hospital, \\
involving informal caregivers of \\
persons with dementia and also \\
reflecting on the perceptions of \\
care rendered. Moreover, study \\
design (both qualitative and \\
quantitative) to include primary \\
data from caregivers. \\
Studies with no full text \\
available or non-English \\
language were excluded.
\end{tabular} & \begin{tabular}{|l} 
Two researchers \\
independently analyzed \\
the studies to identify \\
their level of evidence \\
and the themes for the \\
12 studies that met y \\
papers met the inclusion \\
criteria.
\end{tabular} & $\begin{array}{l}\text { Informal carers } \\
\text { 'perspectives is vital to } \\
\text { assure best practice service } \\
\text { delivery for dementia } \\
\text { patients in the hospital } \\
\text { The caregiver must be } \\
\text { involved in the care } \\
\text { recipient's care during } \\
\text { hospitalization for dignified } \\
\text { treatment of persons with } \\
\text { dementia. } \\
\text { Patient care, Staff } \\
\text { interactions, 'Carer's } \\
\text { situation, and Hospital } \\
\text { environment were four } \\
\text { domains identified for best } \\
\text { practices of care delivery }\end{array}$ & \begin{tabular}{|l|} 
Many factors such as \\
staff education, \\
assistance with \\
provision of with \\
personal care needs, \\
and person-centered \\
care approach for \\
patients can help \\
enhance the \\
hospitalization journey \\
for both the person \\
with dementia and \\
carer.
\end{tabular} \\
\hline $\begin{array}{l}\text { Hirschman, K. } \\
\text { B., \& Hodgson, } \\
\text { N. A. (2018). } \\
\text { Evidence-based } \\
\text { interventions } \\
\text { for transitions } \\
\text { in care for } \\
\text { individuals } \\
\text { living with } \\
\text { dementia. The } \\
\text { Gerontologist, } \\
\text { 58, S129-S140. }\end{array}$ & \begin{tabular}{|l} 
Systematic \\
Review \\
Level I \\
High Quality
\end{tabular} & $\begin{array}{l}\text { The authors explore } 7 \\
\text { studies to investigate if } \\
\text { the available evidence } \\
\text { can enhance delivery } \\
\text { care for persons with } \\
\text { dementia and their } \\
\text { caregivers during } \\
\text { transitional care } \\
\text { Possible questions } \\
\text { analyzed: Q } 1 \text {-- What } \\
\text { is the effect of each } \\
\text { intervention on each? }\end{array}$ & $\begin{array}{l}\text { Databases such as } \\
\text { PubMed, CINAHL, } \\
\text { PsycINFO, EMBASE, } \\
\text { ProQuest, Google } \\
\text { Scholar and Cochrane } \\
\text { Collaborative were } \\
\text { searched Search terms } \\
\text { included terms for } \\
\text { transitional care, } \\
\text { dementia or cognitive } \\
\text { impairment }\end{array}$ & $\begin{array}{l}\text { Inclusion criteria considered: } \\
\text { intervention regarding } \\
\text { transitions in care with } \\
\text { following outcomes to delay } \\
\text { placement and diminish } \\
\text { resource use, and participants } \\
\text { with any form of dementia. } \\
\text { Studies with no intervention } \\
\text { and not specific to transitional } \\
\text { care were excluded }\end{array}$ & \begin{tabular}{|l|}
7 studies provided data \\
where 7 interventions \\
were identified. \\
Transitional Care \\
Model, and Dementia \\
Caregiver Training \\
Program (begins in the \\
hospital setting), \\
MIND at Home, \\
Partners in Care and \\
NYU Model (begin at \\
home) and Geriatric \\
Team Intervention, and
\end{tabular} & $\begin{array}{l}\text { Preparation and education } \\
\text { of the caregiver is } \\
\text { paramount and must be } \\
\text { done before, during and } \\
\text { after any transition of care. } \\
\text { That communication by the } \\
\text { caregiver must be thorough, } \\
\text { accurate, appropriate in } \\
\text { length and completed } \\
\text { timely for safe handoff to } \\
\text { unfamiliar providers } \\
\text { As dementia progresses that } \\
\text { communication must be }\end{array}$ & $\begin{array}{l}\text { A patient-centered } \\
\text { approach is vital to } \\
\text { meet the needs of the } \\
\text { patient with dementia } \\
\text { and enhance care } \\
\text { outcomes. } \\
\text { The caregiver for the } \\
\text { person with dementia } \\
\text { is a fundamental } \\
\text { member in } \\
\text { communicating those } \\
\text { needs across } \\
\text { healthcare settings }\end{array}$ \\
\hline
\end{tabular}




\begin{tabular}{|c|c|c|c|c|c|c|c|}
\hline \begin{tabular}{|l|} 
https://academi \\
c.oup.com/gero \\
ntologist/article \\
158/suppl_1/S1 \\
$29 / 4816738$ \\
\end{tabular} & & $\begin{array}{l}\text { Q } 2 \text {-- What is the effect } \\
\text { of all interventions on } \\
\text { transitions of care? }\end{array}$ & & & $\begin{array}{l}\text { Goals of Care } \\
\text { Intervention are long } \\
\text { term care appropriate } \\
\text { interventions }\end{array}$ & $\begin{array}{l}\text { appropriately updated to } \\
\text { reflect the needs at the time } \\
\text { and ensure positive } \\
\text { outcomes }\end{array}$ & $\begin{array}{l}\text { Interventions for } \\
\text { success are } \\
\text { multicomponent. } \\
\text { Partnership and } \\
\text { effective } \\
\text { communication } \\
\text { between family } \\
\text { caregivers and } \\
\text { providers within } \\
\text { healthcare settings are } \\
\text { proven to lead to } \\
\text { decreased hospital } \\
\text { length of stay }\end{array}$ \\
\hline $\begin{array}{l}\text { Wu, Q., Qian, } \\
\text { S., Deng, C., \& } \\
\text { Yu, P. (2020). } \\
\text { Understanding } \\
\text { Interactions } \\
\text { Between } \\
\text { Caregivers and } \\
\text { Care Recipients } \\
\text { in Person- } \\
\text { Centered } \\
\text { Dementia Care: } \\
\text { A Rapid } \\
\text { Review. } \\
\text { Clinical } \\
\text { Interventions in } \\
\text { Aging, 15, } \\
\text { 1637-1647. } \\
\text { https://doi.org/1 } \\
\text { 0.2147/CIA.S2 } \\
\text { 55454 } \\
\end{array}$ & $\begin{array}{l}\text { Systematic } \\
\text { Review } \\
\text { Level I } \\
\text { High quality } \\
\end{array}$ & $\begin{array}{l}\text { Q1 --What is the effect } \\
\text { of intervention } \\
\text { approaches in person- } \\
\text { centered dementia care } \\
\text { approach? } \\
\text { Q2 - Does using } \\
\text { intervention approaches } \\
\text { promote person- } \\
\text { centered care for } \\
\text { dementia patients? }\end{array}$ & $\begin{array}{l}\text { Full texts were searched } \\
\text { in both MEDLINE and } \\
\text { CINAHL Plus for the } \\
\text { following terms: } \\
\text { "interaction", "person- } \\
\text { cent"", "relationship- } \\
\text { cent"" and "dementia". }\end{array}$ & $\begin{array}{l}\text { Inclusion criteria included } \\
\text { studies describing person- } \\
\text { centered dementia care, and the } \\
\text { interactions between caregivers } \\
\text { (both paid and informal) and the } \\
\text { perspn with dementia getting } \\
\text { care. elements of person- } \\
\text { centered dementia care, } \\
\text { Studies not discussing dementia } \\
\text { care, person-centered care, the } \\
\text { actual interaction between } \\
\text { caregivers and persons with } \\
\text { dementia met the exclusion } \\
\text { criteria. } \\
\text { Conferences, editorials, } \\
\text { dissertations, and book contents } \\
\text { were also excluded. }\end{array}$ & $\begin{array}{l}25 \text { articles were } \\
\text { included in this review } \\
\text { Two different authors } \\
\text { screened the studies } \\
\text { independently screened } \\
\text { half of the articles, } \\
\text { compared their } \\
\text { screening results } \\
\text { through cross-check } \\
\text { each other's extraction, } \\
\text { then resolved any } \\
\text { disagreement. }\end{array}$ & $\begin{array}{l}\text { Asa result of person- } \\
\text { centered dementia care, } \\
\text { three outcomes were noted: } \\
\text { social well-being, } \\
\text { psychological well-being } \\
\text { and physical well-being. } \\
\text { Good interactions between } \\
\text { caregivers and the care } \\
\text { recipients can lead to great } \\
\text { collaboration among both } \\
\text { parties for enhanced care } \\
\text { delivery. }\end{array}$ & $\begin{array}{l}\text { Interaction between } \\
\text { informal caregivers } \\
\text { and person with } \\
\text { dementia receiving } \\
\text { care are vital to assure } \\
\text { a person-centered care } \\
\text { approach. } \\
\text { Formal/paid } \\
\text { caregivers should } \\
\text { maintain that } \\
\text { interaction with care } \\
\text { recipients with } \\
\text { dementia. In } \\
\text { organizations, } \\
\text { appropriate resources } \\
\text { are necessary to } \\
\text { facilitate those } \\
\text { interpersonal relations } \\
\text { such as a competent } \\
\text { workforce, less } \\
\text { changes in staff, a } \\
\text { dementia-friendly } \\
\text { environment. } \\
\text { Management must be } \\
\text { supportive of the } \\
\text { approach to assure } \\
\text { sustainability of } \\
\text { person-centered } \\
\text { dementia care in } \\
\text { organizations. }\end{array}$ \\
\hline
\end{tabular}




\section{Appendix C}

\section{SWOT Analysis}

\begin{tabular}{|c|c|}
\hline \multicolumn{2}{|c|}{ INTERNAL FACTORS } \\
\hline STREGHTS (+) & WEAKNESSES (-) \\
\hline Facility supportive of EBP project & $\begin{array}{l}\text { No patient education regarding safe transfer to the } \\
\text { hospital }\end{array}$ \\
\hline $\begin{array}{l}\text { Facility with reputation to support the well-being } \\
\text { and the experience of the dyad (i.e., informal } \\
\text { caregivers and the person with dementia) }\end{array}$ & No standardized needs communication plan \\
\hline Intervention is a low-cost strategy & $\begin{array}{l}\text { The Director of Family Nurse Consultant (FNC) role is } \\
\text { vacant }\end{array}$ \\
\hline $\begin{array}{l}\text { Facility with excellent crisis management } \\
\text { resources for caregivers }\end{array}$ & $\begin{array}{l}\text { The Vice President of Community Services position is } \\
\text { vacant }\end{array}$ \\
\hline $\begin{array}{l}\text { Facility in line with non-pharmacological } \\
\text { interventions for PWD and caregivers }\end{array}$ & $\begin{array}{l}\text { Difficulty to provide standardized care needs } \\
\text { communication tool to caregivers }\end{array}$ \\
\hline
\end{tabular}

\section{EXTERNAL FACTORS}

\begin{tabular}{|l|l|}
\hline \multicolumn{1}{|c|}{ OPPORTUNITIES (+) } & \multicolumn{1}{c|}{ THREATS (-) } \\
\hline $\begin{array}{l}\text { Opportunity to improve (OTI) caregivers' QOL } \\
\text { and care recipient's experience during } \\
\text { hospitalization }\end{array}$ & Caregivers forget to complete the form \\
\hline $\begin{array}{l}\text { OTI for the care recipient's experience and health } \\
\text { outcomes during hospitalization }\end{array}$ & Form is not within reach when caregivers need to use it \\
\hline $\begin{array}{l}\text { Opportunity for caregivers to embrace increased } \\
\text { quality of dementia care, and decreased anxiety }\end{array}$ & $\begin{array}{l}\text { Decreased utilization of the tool due to COVID 19 } \\
\text { pandemic }\end{array}$ \\
\hline & $\begin{array}{l}\text { Decreased interaction between the FNC and the caregiver } \\
\text { to educate about the tool due to the COVID pandemic }\end{array}$ \\
\hline
\end{tabular}




\section{Appendix D}

\section{Project Schedule}

\begin{tabular}{|c|c|c|c|c|c|c|c|c|c|c|c|c|c|c|c|c|c|c|c|c|c|c|c|c|}
\hline & & $\mathrm{R} 78$ & & & & & & & & R78 & & & & & & & & 7803 & & & & & & \\
\hline 㟒 & $\begin{array}{l}\frac{7}{5} \\
\frac{\pi}{3} \\
3\end{array}$ & $\begin{array}{l}m \\
\frac{1}{0} \\
3 \\
3\end{array}$ & $\begin{array}{l}n \\
\frac{4}{0} \\
\frac{d}{3}\end{array}$ & $\begin{array}{l}\text { N } \\
\frac{1}{0} \\
3 \\
3\end{array}$ & $\begin{array}{l}a \\
\frac{u}{0} \\
3\end{array}$ & $\begin{array}{l}= \\
\frac{\pi}{ \pm} \\
3\end{array}$ & $\begin{array}{l}\frac{m}{2} \\
\frac{y}{8} \\
3\end{array}$ & $\begin{array}{l}n \\
\frac{n}{0} \\
\frac{0}{3}\end{array}$ & $\begin{array}{l}\bar{y} \\
\frac{y}{d} \\
3\end{array}$ & $\begin{array}{l}m \\
\frac{n}{0} \\
\frac{0}{3} \\
3\end{array}$ & $\begin{array}{l}n \\
\frac{1}{0} \\
\frac{0}{3}\end{array}$ & $\frac{5}{2}$ & $\begin{array}{l}9 \\
\frac{1}{0} \\
3\end{array}$ & $\begin{array}{l}= \\
\frac{\pi}{ \pm} \\
3\end{array}$ & $\begin{array}{l}\frac{m}{2} \\
\frac{y}{2} \\
\frac{d}{3}\end{array}$ & $\begin{array}{l}\frac{n}{4} \\
\frac{4}{0} \\
3\end{array}$ & $\frac{7}{\sqrt{0}}$ & $\begin{array}{l}m \\
\frac{n}{0} \\
\frac{0}{3} \\
3\end{array}$ & $\begin{array}{l}n \\
\frac{n}{0} \\
3 \\
3\end{array}$ & $\begin{array}{l}\frac{1}{0} \\
\frac{0}{3} \\
3\end{array}$ & $\begin{array}{l}\frac{a}{d} \\
\frac{1}{3}\end{array}$ & $\begin{array}{l}= \\
\frac{\pi}{8} \\
3 \\
3\end{array}$ & $\begin{array}{l}\frac{m}{4} \\
\frac{\pi}{0} \\
3\end{array}$ & $\frac{n}{\frac{y}{d}}$ \\
\hline Meet with preceptor & $\mathrm{x}$ & $\mathrm{x}$ & & $\mathrm{x}$ & & & & & & & & & & & & & & & & & & & & \\
\hline $\begin{array}{l}\text { Conduct needs } \\
\text { assessment }\end{array}$ & $\mathrm{x}$ & $\mathrm{x}$ & & & & & & & & & & & & & & & & & & & & & & \\
\hline $\begin{array}{l}\text { Conduct literature } \\
\text { search }\end{array}$ & & $\mathrm{x}$ & $\mathrm{x}$ & $\mathrm{x}$ & & & & & & & & & & & & & & & & & & & & \\
\hline $\begin{array}{l}\text { Develop project } \\
\text { proposal }\end{array}$ & $\mathrm{x}$ & $\mathrm{x}$ & $\mathrm{x}$ & $\mathrm{x}$ & $\mathrm{x}$ & $\mathrm{x}$ & $\mathrm{x}$ & & & & & & & & & & & & & & & & & \\
\hline $\begin{array}{l}\text { Obtain project } \\
\text { stakeholder approval }\end{array}$ & & & & & & & & $\mathrm{x}$ & $\mathrm{x}$ & $\mathrm{x}$ & $\mathrm{x}$ & $\mathrm{x}$ & & & & & & & & & & & & \\
\hline Submit the USA IRB & & & & & & & & & & & & & $\mathrm{x}$ & & & & & & & & & & & \\
\hline $\begin{array}{l}\text { Submit to the facility } \\
\text { EBP committee }\end{array}$ & & & & & & & & & & & & & & $\mathrm{x}$ & & & & & & & & & & \\
\hline $\begin{array}{l}\text { Obtain USA EBP } \\
\text { committee approval }\end{array}$ & & & & & & & & & & & & & & & $\mathrm{x}$ & & & & & & & & & \\
\hline $\begin{array}{l}\text { Obtain facility IRB } \\
\text { approval }\end{array}$ & & & & & & & & & & & & & & & & $\mathrm{x}$ & & & & & & & & \\
\hline $\begin{array}{l}\text { Proceed with training } \\
\text { for plan of care needs } \\
\text { communication tool } \\
\text { for Family Nurse } \\
\text { Consultants (FNCs) }\end{array}$ & & & & & & & & & & & & & & & & & $\mathrm{x}$ & & & & & & & \\
\hline $\begin{array}{l}\text { Implementation of the } \\
\text { clinician-caregiver } \\
\text { communication form }\end{array}$ & & & & & & & & & & & & & & & & & & $\mathrm{x}$ & $\mathrm{x}$ & $\mathrm{x}$ & & & & \\
\hline $\begin{array}{l}\text { Data collection to } \\
\text { monitor FNCs' } \\
\text { perception of the value }\end{array}$ & & & & & & & & & & & & & & & & & & & $\mathrm{x}$ & $\mathrm{x}$ & & & & \\
\hline
\end{tabular}




\begin{tabular}{|c|c|c|c|c|c|c|c|c|c|c|c|c|c|c|c|c|c|c|c|c|c|c|c|c|}
\hline & \multicolumn{8}{|c|}{ NUR7801 } & \multicolumn{8}{|c|}{ NUR7802 } & \multicolumn{8}{|c|}{ NUR7803 } \\
\hline 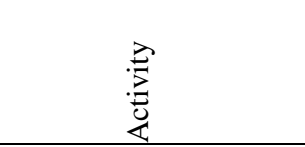 & $\frac{7}{3}$ & $\frac{m}{3}$ & $\begin{array}{l}n \\
\frac{4}{0} \\
3\end{array}$ & $\frac{5}{3}$ & $\frac{a}{\frac{a}{3}}$ & $\begin{array}{l}= \\
\frac{y}{8} \\
\frac{8}{3}\end{array}$ & $\frac{m}{2}$ & $\begin{array}{l}\frac{n}{4} \\
\frac{u}{d} \\
\frac{3}{3}\end{array}$ & $\frac{\sqrt{4}}{2}$ & $\frac{n}{\frac{y}{d}}$ & $\begin{array}{l}n \\
\frac{2}{2} \\
\frac{0}{3}\end{array}$ & $\frac{\pi}{3}$ & $\begin{array}{l}\frac{a}{0} \\
\frac{u}{3} \\
3\end{array}$ & $\begin{array}{l}= \\
\frac{y}{0} \\
\frac{0}{3}\end{array}$ & $\begin{array}{l}m \\
\frac{n}{0} \\
\frac{1}{3}\end{array}$ & $\begin{array}{l}\frac{n}{4} \\
\frac{4}{0} \\
3\end{array}$ & $\frac{\sqrt{4}}{3}$ & $\begin{array}{l}\frac{n}{d} \\
\frac{u}{3} \\
3\end{array}$ & $\begin{array}{l}n \\
\frac{n}{0} \\
3\end{array}$ & $\frac{\pi}{3}$ & $\begin{array}{l}\frac{9}{1} \\
\frac{y}{3}\end{array}$ & $\begin{array}{l}z \\
\frac{x}{d} \\
3\end{array}$ & $\begin{array}{l}m \\
\frac{n}{0} \\
3\end{array}$ & $\begin{array}{l}n \\
\frac{y}{d} \\
\frac{d}{3}\end{array}$ \\
\hline $\begin{array}{l}\text { of the tool and its } \\
\text { benefit to the caregiver }\end{array}$ & & & & & & & & & & & & & & & & & & & & & & & & \\
\hline Final data collection & & & & & & & & & & & & & & & & & & & & $\mathrm{x}$ & & & & \\
\hline $\begin{array}{l}\text { Data Analysis using } \\
\text { the statistical software }\end{array}$ & & & & & & & & & & & & & & & & & & & & $\mathrm{x}$ & & & & \\
\hline $\begin{array}{l}\text { Compare baseline data } \\
\text { to post implementation } \\
\text { of intervention (data } \\
\text { evaluation) }\end{array}$ & & & & & & & & & & & & & & & & & & $\mathrm{x}$ & $\mathrm{x}$ & $\mathrm{x}$ & & & & \\
\hline $\begin{array}{l}\text { Evaluate feasibility } \\
\text { and sustainability of } \\
\text { intervention model }\end{array}$ & & & & & & & & & & & & & & & & & & & & $\mathrm{x}$ & $\mathrm{x}$ & $\mathrm{x}$ & $\mathrm{x}$ & \\
\hline $\begin{array}{l}\text { Dissemination of } \\
\text { findings to } \\
\text { organization's } \\
\text { stakeholders }\end{array}$ & & & & & & & & & & & & & & & & & & & & & $\mathrm{x}$ & $\mathrm{x}$ & & \\
\hline
\end{tabular}




\section{Appendix E}

\section{Family Nurse Consultant Self-Evaluation -- Pre-Project}

\section{Title of DNP Scholarly Project:}

Partnering with Hospital Providers to Facilitate Handoff for Persons with Dementia in the Acute Care Setting.

Thank you participating in this project. By answering these questions, you consent to participate in the project. Please print your initials at bottom left section in the form. Please circle the most appropriate answer that best describes you.

I am familiar with the most important things a caregiver needs to share about his loved one with cognitive impairment to hospital staff.
1. Strongly Disagree
2. Disagree
3. Agree
4. Strongly Agree

I believe it is vital for the caregiver to share vulnerabilities about the person with dementia during hospitalization and transition of care.
1. Strongly Disagree
2. Disagree
3. Agree
4. Strongly Agree

I am concerned about the person with dementia during transitions of care due to the caregiver's inability to communicate care needs to hospital personnel
1. Strongly Disagree
2. Disagree
3. Agree
4. Strongly Agree

I perceive the caregiver's input in acute care and transition of care to be positive for the welfare of the person with dementia. 
$\begin{array}{llll}\text { 1. Strongly Disagree } & \text { 2. Disagree } & \text { 3. Agree } & \text { 4. Strongly Agree }\end{array}$

I am concerned that hospital staff may not know enough about the unique needs of patients with Alzheimer's disease or related neurocognitive disorders.
1. Strongly Disagree
2. Disagree
3. Agree
4. Strongly Agree

FNC Initials 


\section{Appendix F}

\section{Family Nurse Consultant Self-Evaluation -- Post-Project}

\section{Title of DNP Scholarly Project:}

Partnering with Hospital Providers to Facilitate Handoff for Persons with Dementia in the Acute Care Setting.

You are receiving this survey via email because you have agreed to participate in the project.

Please print your initials at the bottom left section in the form. Please circle the most appropriate answer that best describes you.

I see the value in providing the communication tool proactively to caregivers as a means of improving patient safety during hospitalization.
1. Strongly Disagree
2. Disagree
3. Agree
4. Strongly Agree

I perceive the tool as a form of empowerment for the caregivers who will use the tool.
1. Strongly Disagree
2. Disagree
3. Agree
4. Strongly Agree

I believe I can educate caregivers with the tool so that they can properly present the vulnerabilities of the cognitively impaired person with hospital staff.
1. Strongly Disagree
2. Disagree
3. Agree
4. Strongly Agree

I believe the caregivers will have a positive impact in acute care and transitions of care when the form is used as a tool to plan and communicate care needs.
1. Strongly Disagree
2. Disagree
3. Agree
4. Strongly Agree 
I perceive this change in practice can help minimize disruptions for the person with dementia during a hospital length of stay.
1. Strongly Agree
2. Agree
3. Disagree
4. Strongly Disagree

FNC Initials 


\section{Appendix G}

\section{Family Nurse Consultant Self-Evaluation -- Post-Project (30 days post presentation) Title of DNP Scholarly Project:}

Partnering with Hospital Providers to Facilitate Handoff for Persons with Dementia in the Acute Care Setting.

You receive this survey 30 days from the day of project implementation because you have agreed to participate in the project. Please print your initials at the bottom left section in the form. Circle the most appropriate answer that best describes you.

Have you encountered a caregiver who has benefited from this time of preparation for their loved ones with dementia?
1. Strongly Disagree
2. Disagree
3. Agree
4. Strongly Agree

The tool offers a way to organize thoughts that increase communication between the family member and the next care team.
1. Strongly Disagree
2. Disagree
3. Agree
4. Strongly Agree

I am comfortable discussing the communication care needs tool with caregivers for persons with dementia.
1. Strongly Disagree
2. Disagree
3. Agree
4. Strongly Agree

I value this tool as another approach for caregivers to safeguard their loved ones with dementia in the acute care setting. 

1. Strongly Disagree
2. Disagree
3. Agree
4. Strongly Agree

How many times have you used this form since your participation in the project?
A. 0
B. 1
C. 2
D. 3
E. 4
F. 5 or more

FNC Initials 


\section{Appendix H}

\section{Clinician-Caregiver Communication Form}

Complete this form for the person with dementia to better prepare for hospitalization. Please update this form as needed with new information to adjust the needs of the person with dementia. Upon completion, secure the form in a Ziploc bag and attach it on the refrigerator.

Patient Name: Date of birth:

Age:

Please answer these questions to better assist the hospital team to provide better care to the patient.

Does the person you care for has a neurocognitive disorder? If yes, which one?

$\square$ Alzheimer's disease $\quad \square$ Lewy body dementia $\quad \square$ Frontotemporal $\quad \square$ Vascular dementia

$\square$ Parkinson related dementia $\quad \square$ Mixed dementia $\quad \square$ Head trauma/chronic traumatic encephalopathy

Cognitive status/mood: alert awake non-verbal calm confused smiling

History of wandering $\square$ Yes $\square$ No $\quad$ If yes, does he/she have a device locator? $\square$ Yes $\square$ No

\section{Assistive Device}

Does the person you care for wear glasses? $\square$ Yes $\square$ No $\quad$ If yes, present on admission?

Does he/she wear hearing aid? $\square$ Yes $\square$ No $\quad$ If yes, present on admission? -------

Does he/she wear denture? $\square$ Yes $\square$ No If yes, $\square$ partial $\square$ complete Present on admission? Yes $\square$ No

List all other assistive devices used at home:

Nutrition: $\square$ Independent $\square$ Self-feed with tray set up $\square$ Requires assistance with eating $\square$ Total assist Swallowing difficulty $\quad$ Liquid: $\square$ thin $\square$ thickened $\square$ Favorite beverage

Snack during the day Snack at night

Activities and Hobbies: $\square$ Art $\quad \square$ Music Favorite Television show Cards Bingo

Personal Soothing Items: $\quad \square$ Toys/Games/Puzzles $\quad \square$ Stuffed Animal $\quad \square$ Blanket Pillow

Additional Comments:

Routine with Personal Care:

\begin{tabular}{|l|l|l|l|}
\hline & No Assistance & With Assistance & \\
\hline Toileting & & & Incontinent: $\square$ Bowel \\
\hline
\end{tabular}




\begin{tabular}{|l|l|l|l|}
\hline & & & Incontinent: $\square$ Bladder \\
\hline Shower/ Bath & & & Time of the day: \\
\hline Dressing & & & \\
\hline
\end{tabular}

Mobility:

\begin{tabular}{|l|l|l|l|}
\hline & No Assistance & With Assistance & Assistive Device \\
\hline Transferring & & & \\
\hline Walking & & & \\
\hline
\end{tabular}

Additional Comments:

Are you the patient's caregiver? $\square$ Yes $\square$ No If No, Relationship to Patient:

Phone number: 